\title{
Assessing long-term habitability at an eastern Sahara oasis: ESR dating of molluscs and herbivore teeth at Dakhleh Oasis, Egypt
}

M.R. Kleindienst ${ }^{a^{*}}$, B.A.B. Blackwell ${ }^{b, c}$, A.R. Skinner ${ }^{b, c}$, C.S. Churcher ${ }^{\mathrm{e}}$, J.M. Kieniewicz ${ }^{\mathrm{d}+}$, J.R. Smith $^{d}$, N.L. Wise ${ }^{b}$, R.A. Long ${ }^{c, \ddagger}$, A.E. Deely ${ }^{c}$, J.I.B. Blickstein ${ }^{c}$, K.K.L. Chen ${ }^{c}$, A. Huang ${ }^{c}$, M.O.D. $\mathrm{Kim}^{\mathrm{c}}$

a Dept. of Anthropology, University of Toronto at Mississauga, Mississauga, ON, L5L 1C6, Canada.*

${ }^{b}$ Dept. of Chemistry, Williams College, Williamstown, MA, 01267, USA.

Anne.R.Skinner@williams.edu

Bonnie.A.B.Blackwell@williams.edu

${ }^{c}$ RFK Science Research Institute, Glenwood Landing, NY, 11547-0866, USA,

${ }^{d}$ Dept. of Earth \& Planetary Sciences, Washington University in St. Louis, St. Louis, MO, 631304862, USA.

jensmith@levee.wustl.edu

jomakie@gmail.com

e Dept. of Zoology, University of Toronto, Toronto, ON, M5S 3G5, Canada.

rchurcher@shaw.ca

\begin{abstract}
In the northeastern Sahara, electron spin resonance (ESR) dating of when animals lived documents their habitability in Dakhleh Oasis, Egypt. A Middle Pleistocene paleolake(s) covered $>1700 \mathrm{~km}^{2}$. At eastern Locality Dak348, $10 \mathrm{~m}$ thick, remnant lacustrine marls yielded Pleistocene fauna, rare artefacts, and plant casts. No obvious unconformity exists within these deposits. From upper horizons, a hartebeest tooth ESR dated at $195 \pm 11$ ka, correlates with Marine Isotope Stage (MIS) 7, while molluscs from a stratigraphically higher horizon averaged $89 \pm 10 \mathrm{ka}$, correlating with MIS 5a/b. At western Locality Dak006, upslope deflation has left a temporally mixed surficial lag. Numerous lagged tooth fragments, independently dated by ESR, correlate with MIS 5 through 17. Fragments from a slope sand unit correlate with MIS stages 3 through 6. One bovid tooth associated with Younger Middle Stone Age artefacts in the base of the sand dated at $84 \pm 7 \mathrm{ka}$ (MIS 5a/b). Molluscs from Romano-Byzantine backdirt at a breached artesian vent dated to 8-15 $\pm 1 \mathrm{ka}$, suggesting that ponds formed during MIS 1 and 2 . Even without well defined sedimentary contexts, ESR frequency data indicate that the oasis was habitable for herbivores during at least twelve stages in the Mid-Late Quaternary, and, therefore, likely also for humans.
\end{abstract}

Key words: Dakhleh Oasis; Egypt; Sahara; electron spin resonance; Middle Stone Age; palaeoenvironments

\footnotetext{
* Corresponding Author: 1762 Angela Crescent, Mississauga, ON, Canada L5J 1B9 maxine.kleindienst@utoronto.ca \& +01-905-855-8488

$\dagger \quad$ Current address: Institute of Physics, 76 Portland Place, London W1B 1NT. UK.

‡ Now publishing using married name, Rebecca A.L. Baylon.
} 


\section{Introduction}

When we address the processes of 'greening' the Sahara during multiple Pleistocene periods, the roles played by long-lasting oases serving as refugia for vegetation and fauna--and humans--should be considered (cf. Larrasoaña, 2012; Smith, 2012; Foley et al., 2013; Larrasoaña et al., 2013). One such oasis is Dakhleh Oasis (also Dakhla or Dakla) in the Egyptian Western Desert, the largest in both modern population and cultivated area (Fig. 1). The administrative center, Mut, lies at $25^{\circ} 29^{\prime} \mathrm{N}, 29^{\circ} 00^{\prime} \mathrm{E}, \sim 600 \mathrm{~km}$ southwest of Cairo, and $\sim 280 \mathrm{~km}$ by road from the Nile Valley at Assiut. In the same physiographic area (Hermina, 1990), the neighboring Kharga Oasis is $180 \mathrm{~km}$ to the east, closer to the Nile Valley. The modern cultivated Dakhleh Oasis and the wider extent of the 'palaeo-oasis' occupy two deflated eastern and western Lowland basins, separated by an eroded sandstone ridge representing the uplifted Tawil Anticline. The bounding steep Escarpment that edges the Libyan Plateau on the north and northeast rises to $>400 \mathrm{~m}$ above the lowest points in western Dakhleh at $\sim 100 \mathrm{~m}$ a.s.l. To the south lies the Dharb el-Arbain (or Nubian) Desert.

The Dakhleh Oasis Project (DOP) has conducted archaeological and environmental research in the oasis region, starting in 1977. DOP is a long-term, multidisciplinary study by archaeologists, earth scientists and other environmentalists (Churcher and Mills, 1999; Hope and Mills, 1999; Marlow and Mills, 2000; Hope and Bowen, 2002; Bowen and Hope, 2003; Thurston, 2003; Wiseman, 2008; Bagnall et al., 2012). Evidence for human occupations ranges from that of Pleistocene and Holocene prehistoric times through the Historic Period to Medieval Islamic times, and to the present day (Kleindienst et al., 1999).

Holocene prehistoric cultural units and environmental changes are relatively well dated (McDonald, 2001, 2009). However, few chronometric ages have been reported for Pleistocene deposits; some determinations are as yet unpublished. ${ }^{230} \mathrm{Th} /{ }^{234} \mathrm{U}$ dates on redeposited tufa blocks and calcretes constrain the ages of some deposits of gravels and eroded lakebeds (Churcher et al., 1999; Kleindienst et al., 1999; Kleindienst et al., 2008). Dakhleh Glass, a melt rock formed when an asteroid exploded in a catastrophic airburst or impact, occurs embedded in or lagged on some Pleistocene lacustrine deposits (Kleindienst et al., 2006; Kieniewicz, 2007; Osinski et al., 2007; Osinski et al., 2008; Schwarcz et al., 2008). A limiting date during deposition for these outcrops is provided by ${ }^{39} \mathrm{Ar} /{ }^{40} \mathrm{Ar}$ ages on the glass averaging $145 \pm 19 \mathrm{ka}$ and adjusted to $146 \mathrm{ka}$ (Renne et al., 2010). Dakhleh region was adversely affected for some time (Smith et al., 2009). Thus, the ESR (electron spin resonance) dates reported herein significantly increase the geochronological database for reconstructing palaeoenvironments.

\section{Regional Setting}

Today, in the hyperarid desert, Dakhleh Oasis life and irrigation agriculture totally depend upon deep boreholes tapping the Nubian Sandstone Aquifer (Ebraheem et al., 2004; Gossel et al., 2004; Kato et al., 2012; Sefelnasr et al., 2014) and some short-lived shallow wells. Annual precipitation approaches nil (Vose et al., 1992), although some heavy or persistent rains have been recorded, most recently in 2008 and 2014. In the Pleistocene, however, surface water was present. Numerous fossil artesian spring vents brought water to the surface from the Nubian Aquifer (Kleindienst et al., 1999; Adelsberger and Smith, 2010), and large lakes and wetlands existed (Churcher et al., 1999; Kleindienst et al., 1999; Kieniewicz, 2007; Kieniewicz and Smith, 2009; Churcher and Kleindienst, n.d.). On the Escarpment face three areas with 
poorly preserved, spring-deposited tufa terraces were located, and redeposited tufa boulders indicate other areas of deposition. Two terraces were ${ }^{230} \mathrm{Th} /{ }^{234} \mathrm{U}$ dated to $>200 \mathrm{ka}$. Tufas mark where surface water flowed from the north into the Lowland, as do wadi cuts into the Escarpment. The modern sand sheet and dune belt obscure a large southern catchment area draining into the western basin (Kieniewicz and Smith, 2009). Eroded, terraced remnants belonging to at least three periods of fan/bajada formation below the Escarpment provide additional evidence (Brookes, 1986; 1993; Kleindienst et al., 1999). The P-I, P-II, and P-III (or $\mathrm{P} / \mathrm{B}$ ) geomorphic surfaces (Fig. 2) bear fluvial boulder gravels that extend far south into the central and eastern lowlands, indicating multiple periods of more vigorous precipitation in the past. On the Escarpment face, evidence for slumping, landslides and debris flows reflect times when shales underlying the limestone cap rocks of the Libyan Plateau were saturated. Scattered fossil faunal remains (Churcher, 1999b, a; Churcher et al., 1999; Churcher et al., 2008), and scarce vegetal remains (Thanheiser, 2008) also provide evidence that palaeoenvironmental conditions allowed an African savannah to develop during and after the later Middle Pleistocene.

In the following sections, Localities of archaeological interest and study are indicated by DakXXX. Field Sample numbers (DXXX) refer to pieces collected within the same area; Analyzed Sample numbers (e.g. FTXX, RMXX, etc.) refer to pieces from field samples that were suitable for, and dated by, ESR.

\subsection{Dakhleh Oasis Landscapes}

Although by 1980, Churcher (1981) recognized that the sporadic outcrops of CSS (Calcareous Silty Sediments) were probably lacustrine deposits, that was verified only in 1996 when fossil bones and freshwater snail shells were found at 'Snail Hill' (Locality Dak348) (Loc.) in eastern Dakhleh. Searching for and preliminary mapping of deposits followed (Churcher et al., 1999; Churcher and Kleindienst, n.d.). More accurate mapping using differential global positioning (DGPS), and detailed study (Kieniewicz, 2007; Kieniewicz and Smith, 2009), established the past presence of a large palaeolake inundating $1735 \mathrm{~km}^{2}$, given a water surface elevation of $160 \mathrm{~m}$ a.s.I., the elevation of some deposits (Fig. 3). Water levels could have been higher; or multiple lakes might have existed when levels did not overtop the Tawil Anticline ridge. Surface drainage from both north and south, plus some artesian water, fed the lake(s) and wetlands across Dakhleh Lowland. Dedicated searching of the discontinuous, scattered lakebed remnants (Churcher and Kleindienst, 1999) yielded rare fossil bones, but few teeth or tooth fragments for ESR dating, except from the far western Bir Talata, Loc. Dak006. Only Snail Hill (Loc. Dak348) yielded snail shells in quantity in the lakebeds; some were also recovered at Bir Talata from artesian spring vent sediments (below).

In both the eastern Teneida (or Balat/Teneida) Palaeobasin (TPBsn) and the western Kellis Palaeobasin (KPBsn), lacustrine sediments overlie a landscape with considerable relief, showing strong aeolian erosion of bedrocks prior to deposition (Kieniewicz and Smith, 2009). In the east, some Cretaceous Taref Formation (Fm.) sandstone yardangs standing $>10 \mathrm{~m}$ above the modern surface are 'frosted' by lakebeds. At other locations, lacustrine deposits rest on red Mut Fm. claystones, which overlie the sandstone. In north-central KPBsn, the Mut Fm. was eroded into a landscape of yardangs that were buried by sands prior to CSS deposition. Only 3 small outcrops of CSS have been found preserved there. Much of the deeply deflated KPBsn is 
now obscured by moving sand dunes, or is under cultivation, with some larger Late Pleistocene/Holocene playas (Zaghloul et al., 2013). Most CSS outcrops are located in the southeastern KPBsn, and in the western and northeastern TPBsn (Fig. 3). A sand unit sometimes forms the contact bed between the lake marls and bedrocks, although contact beds vary. In places they are 'Red Mud', redeposited from the Mut Fm.

In four localities, highly aeolized, abraded and weathered, Earlier Stone Age (ESA) bifaces lay on eroded bedrock surfaces, underlying lake deposits. Typologically, most are Terminal ESA, Balat Cultural Unit artefacts (cf. Kleindienst, 1999) (Fig. 3). In TPBsn these were found at outcrops in the northeastern area, at the central Loc. Dak436, at the southernmost Loc. Dak390, and in KPBsn at small exposures of CSS south of Mut, Loc. Dak411; the last have been destroyed by the current extension of cultivation. No Balat Unit has been found in the northwestern KPBsn, although some ESA Upper Acheulian finds were located at fossil spring vents or as surface isolates.

Generalized Older Middle Stone Age (OMSA) artefacts were found in basal CSS in both basins. These are assigned to the Teneida Cultural Unit at Locs. Dak361, 374 and 391 in northeastern TPBsn (Fig. 3) (Kleindienst, 2003), and at Loc. Dak397C in southeastern KPBsn. In both areas, Dakhleh Glass was found at higher elevations, indicating an age of >146 ka. Rare artefacts occur sporadically elsewhere within the lake deposits; these are likely water-sorted, but can be considered MSA. In the southwestern TPBsn, generalized Younger MSA (YMSA) occurs in a fossil vent (Loc. Dak153) that erupted through eroded CSS. It was then eroded, and overlain by thick lacustrine sediments. Multiple erosion surfaces here and to the north are marked by calcretes, suggesting multiple lake stages that have, as yet, not been identified. Based upon comparisons with dated localities at Kharga, the oldest OMSA is $>240 \mathrm{ka}$ (Kleindienst et al., 2008), and YMSA must be younger than 140-145 ka Uyrs (Smith et al., 2007).

\subsection{Snail Hill, Archaeological Locality Dak348}

Snail Hill, Loc. Dak348 (DOP Grid 30/435 M2-1, see Churcher and Mills, 1999: Appendix II), is an isolated twin-knolled, remnant of the CSS Member, Lake Teneida Fm., sitting on the eroded Cretaceous Taref Fm. sandstone that forms the southeastern oasis rim in TPBsn (Figs. 3, 4). In the base of the outcrop, numerous Romano-Byzantine grave shafts were cut into the basal lake deposits and underlying bedrock shales. Once a trigonometric point, the top of the northern knoll lies at $151.1 \mathrm{~m}$ a.s.l., with the base of the CSS deposits at $140 \mathrm{~m}$ by DGPS. Thus, it lies within the projected inundation area of Palaeolakes Teneida and Balat. A lens with fossil snail shells outcrops on the southern end of the north summit (Figs. 4, 5), at about $150 \mathrm{~m}$ elevation, mainly comprising fragmented, immature Limnaea stagnalis, but with a mature specimen $>50 \mathrm{~mm}$ long (Churcher et al., 2008). Gyraulis costulatus and Planorbis planorbis also occurred. Blackwell sampled the deposit for ESR dating (Analyzed Samples RM61A, RM68).

Reed stem casts to $40 \mathrm{~mm}$ in diameter in the CSS suggest that the water was relatively shallow. Fossil bone was recovered both from the surface and in situ, and by screening the talus below the snail outcrop. The Iron Balls Fauna here includes (Churcher et al., 1999; Churcher et al., 2008): turtle, Tryonyx sp.; ostrich, Struthio camelus; crane, Grus grus; Mallard duck, Anas platychynchos; long tailed duck, Clangula or Aythya sp.; turnstone, Arenaria 
interpres; hyaena, Hyaena or Crocuta sp.; Cape zebra, Equus capensis; hippopotamus, Hippopotamus amphibius; antelope, large sp.; topi hartebeest, Damaliscus sp.; gazelle, cf. Gazella leptoceres; and extinct giant African buffalo, Pelorovis antiquus. Kieniewicz recovered a hartebeest tooth for ESR dating from the western face of the north knoll, at a slightly lower elevation than that of the snail deposit (Analyzed Sample FT73).

To the west and northwest, across a small wadi, a dispersed concentration of abraded Dakhleh Cultural Unit (Aterian Complex) artefacts lay on uneven, eroded sandstone (Loc. Dak130) (Hawkins, 2001) (Figs. 4, 5). One isolated, heavily abraded tanged piece was found in the surface lag on sandstone north-northeast of Snail Hill, and MSA lithics occur in the lag to the south. However, no Pleistocene artefacts were found in the backdirt from grave digging or looting, so that it is unlikely that any Dakhleh Unit underlies the lakebeds. Churcher found a slightly abraded, small biconical core of 'chert ball chalcedony' in situ, $30 \mathrm{~cm}$ above the basal contact. A few chert artefacts in fresh or mint condition were found on the CSS surface, giving a possible association to Loc. Dak130: a broken MSA-type core trimming flake, 69+ mm long lay on the north end of the remnant, and the talus screening yielded small flaking debris. Other finds are three small end-struck trimming flakes, and a small, struck Levallois core.

\subsection{Bir Talata, Holocene Archaeological Locality Dak006}

As the low number indicates, Bir Talata area in far western Dakhleh (Holocene Loc. Dak006, DOP Grid 32/390 D2-2) was among the first prehistoric localities discovered in 1978 (Churcher, 1980; McDonald, 1980; Churcher, 1981, 1982, 1983). In KPBsn, now deeply deflated, and at a modern surface elevation of $127-130 \mathrm{~m}$ a.s.l., it lies within the projected western edge of Palaeolakes Balat and Kellis, although no lakebeds have been identified (Figs. $3,6,7)$. Based upon elevations, Pleistocene lakebeds could once have been $>20 \mathrm{~m}$ thick.

Sherdage indicates that the area was used in Old Kingdom times. Romano-Byzantine occupants cultivated a large area; they breached artesian spring vents to supply large irrigation canals or aqueducts. Yardanged remnants of 'irrigation deposits' (Brookes, 1989; Kleindienst et al., 1999) stand >2-3 $\mathrm{m}$ high above the modern surface, and represent their irrigated fields (Figs. 6, 7). Yardangs preserved upslope overlie a stony desert lag deposit. On the modern lagged surface, clasts include prehistoric artefacts ranging from mid-Holocene, early Bashendi Cultural Unit A sherds and lithics (cf. McDonald, 2008) together with many bone and tooth fragments, to some abraded MSA Levallois flakes, and indeterminate, larger Pleistocene-type lithics. A blowout exposes red claystones or mudstones underlying the surface lag. Churcher recovered a large bone fragment adjacent to a hammerstone/anvil in situ in 2007, demonstrating that larger clasts occur in the upper $>15 \mathrm{~cm}$ of the deposit, which must be Red Mud; erosion of that has contributed to the surface lag. Whether the underlying deposit is also redeposited, or is bedrock Cretaceous Mut Fm., remains unclear. The claystones overlie Taref Fm. sandstone (cf. Churcher 1981: Fig. 2) (Fig. 8).

Sand dunes of the western dune belt move over the area, obscuring and abrading the surfaces (Fig. 7). The yardanged irrigation deposits and the anthropogenic sediments flanking the aqueducts to the west show that at least 2-3 $\mathrm{m}$ of deposits have been deflated in the past 2,000 years. Comparisons with a sketch map (Churcher, 1981: Fig. 1) shows that significant

amounts of surface material have been removed since 1979, exposing more of the underlying 
Taref sandstone, and creating a mixed-component surface lag. Under the modern dunes, an 'Older Sand Unit' covers the gentle slope to the southwest, overlying sandstone. In places this bears surface concentrations of lagged Bashendi Unit sherds, lithics and comminuted bone (McDonald, pers. comm., 2014). Isolated teeth and fragmented bones and teeth sporadically weather out of the Older Sand Unit. Early Holocene Masara Cultural Unit lithics (cf. McDonald, 2003) were found in the backdirt of one breached artesian vent (Loc. Dak447S), derived from the excavated eye sediments. Further north, snail shells were found in the backdirt of a similar breached vent (Loc. Dak447N).

The Bir Talata area lacks local lithic raw materials. Despite many visits, no Pleistocenetype lithics were found that could not have been imported by Holocene people for recycling. However, in 2008, when the basal Older Sand Unit downslope began to erode, fresh YMSA was exposed in the ferruginized base of the sand overlying altered sandstone bedrock (Loc. Dak445) (Fig. 7). One intact tooth found lying at the contact has been ESR dated (Field Sample D106, Analyzed Sample PT66C). Distinctive in the occurrence of small bifaces and the jagged, notched and denticulated edges on flakes and chunks, the lithics are designated the Bir Talata Cultural Unit. The Tarawan chert used was probably imported over $8 \mathrm{~km}$ from the north.

Identifiable bone eroded out periodically, and was collected between 1979 and 2008 . Fossil fauna recovered from the Loc. Dak006 upslope lag and Red Mud are (Churcher, 1981, 1982, 1983, 1999a; Churcher et al., 1999; Churcher et al., 2008): hippopotamus, Hippopotamus amphibious; extinct giant African buffalo, Pelorovis antiquus and/or African buffalo, Syncerus caffer; hartebeest, cf. Alcelaphus; gazelle, Gazella cf. leproceres and G. cf. dorcas; wild cat, Felis sylvestris lybica; and elephant, Loxodonta africana. A hartebeste and gazelles were also found associated with a lagged Bashendi concentration on the Older Sand Unit downslope to the south. The bones and teeth from upslope were in apparent association with the Bashendi Unit artefacts lying on the Red Mud lag deposit, and at the contact with overlying irrigation deposits (Fig. 8). Consequently, all faunal finds were originally presumed to be Holocene in age, although Churcher et al. (2008) suggested that some might be Pleistocene. In 1979-81, Churcher found elephant tooth fragments in and near the blowout, and later a sample was submitted for preliminary ESR dating. Despite the apparent Holocene association, when dated, the teeth proved to be Middle Pleistocene in age. More tooth fragments from the surface lag around the blowout were then collected for ESR dating, together with associated sediment samples; the results are reported herein (Tables 1 to 7; Fig. 7). Kieniewicz recovered snail shells from the Romano-Byzantine backdirt excavated from the eye of a fossil vent for ESR dating (Loc. Dak447N, Analyzed Samples RM60, RM62) (Fig. 7). These were expected to be Historic Period in age because Melanoides sp. are often found in Romano contexts (Churcher et al., 2008).

\section{Materials and Methods: Electron spin resonance dating (ESR)}

In Dakhleh, the pressure from salts crystallization and dehydration coupled with sand abrasion rapidly reduces bones to unidentifiable shards, even when fossilized. Similarly, teeth suffer abrasion, salt crystallization, and dehydration that tend to separate the enamel from the dentine, while rounding the shards. Because the dentine is softer, it tends to be abraded more rapidly, and hence, is less frequently recovered than the enamel fragments. 
ESR dating is one of the 'trapped charge' methods, which include TL and OSL. In all of these, the dating signal is generated by radiation from the sample itself and from the environment (Rink, 1997). Tooth enamel is considered the optimal material because the ESR signal is stable for well-over several million years (Skinner et al., 2000). Mollusc shells also serve as datable materials although each species must be tested to determine the signal lifetime. Clearly, information is needed about the environmental history of the sample. Samples of all sedimentary units, both loose sediment and solid materials such as roof fall in a cave, within $30 \mathrm{~cm}$ of the tooth or shell should be collected, that reflect the range of sedimentary gamma radiation. In addition, accurate dating requires knowledge of the moisture content, and burial depth, which determines the cosmic dose contribution. ESR dates when the animal lived.

The equation that defines the age of a sample is:

$$
A_{\Sigma}=\int D(t) d t
$$

where $A_{\Sigma}$ is the total radiation dose acquired by the sample subject to a dose rate $D(t)$ from $t=0$ (burial time) to $t=$ (present day). $A_{\Sigma}$ is determined by plotting the ESR signal as a function of dose. For practical purposes this equation becomes:

$$
A_{\Sigma}=\left(A_{\Sigma}\right)_{\text {ext }}+\left(A_{\Sigma}\right)_{\text {int }}
$$

The external and internal components of the total dose are determined separately since the respective dose rates are different. Then to determine age:

$$
\text { Age }=\left\{\left(A_{\Sigma}\right)_{\text {ext }} / D_{\text {ext }}(t)+\left(A_{\Sigma}\right)_{\text {int }} / D_{\text {int }}(t)\right\}
$$

A complication in this field is the absorption of $U$ during burial by teeth (and, to a lesser degree, by some shells), affecting the $D_{\text {int }}$. Classically this led to reporting three possible ages, related to assumptions about U-uptake. Early Uptake (EU) assumes that all $U$ was absorbed shortly after burial and yields the youngest age. Linear Uptake (LU) assumes continuous uptake during burial and Recent Uptake (RU) assumes that a change in the sample environment shortly before excavation led to most of the uptake occurring late in the burial history. RU ages are the oldest of the models. Recently coupled U-series/ESR dating has allowed more precise determination of the model (Grün and McDermott, 1994). However, the tooth fragments found at Dakhleh are too small to allow this second procedure; consequently, results will be reported as model-dependent. Note that the ages agree within experimental uncertainty in many cases, and hence the ages are effectively model-independent. When this is not true, LU ages are generally assumed to be correct; in sites where cross-calibration has been possible between two (or more) dating methods, LU has most often given the best agreement (Porat. and Schwarcz, 1994). However, this cannot be guaranteed for all cases. Sites with RU ages are rare, but not unknown (Blackwell et al., 2007).

Contributors to the external dose are radioisotopes in sediments within $30 \mathrm{~cm}$ of the sample, and cosmic radiation. Where the sediment is non-uniform, dose rates, $D_{\text {ext }}(t)$, are calculated by volumetric averaging of all components, considering the relative position of each component to the sample. In these sites, volumetric averaging was not used. The cosmic dose, $D_{\text {cos }}(t)$, varies with burial depth. Samples found on the surface at Bir Talata must have been buried in the past or they would not have been preserved. As noted, it can be assumed that Pleistocene lakebeds once covered the area (Fig. 3). Thus, the time-averaged dose rate was 
determined by ramped box plot (Deely et al., 2011). An example of this effect at Snail Hill is shown in Table 1. In this and all subsequent tables, the uncertainties in cited ages are determined by experimental uncertainties in $A_{\Sigma}$ and radioisotope concentrations.

\subsection{Sample Preparation}

Teeth samples were prepared using standard enamel protocols (Blackwell, 1989). Tooth fragments were refitted when matches could be found, but then individual fragments were prepared as separate subsamples. After sketching and photographing each tooth or fragment in 2-6 different views, the enamel thicknesses and any associated dentine were measured in 1030 places with a CD-4C digital caliper. The enamel of intact teeth was divided into subsamples, the number varying with tooth size. For each subsample, any attached sediment or dentine was removed from it and saved for NAA. Isolated dentine fragments were also saved for NAA. The enamel thicknesses were measured more precisely in 5-10 places with a Mitutoyo IP-C112E micrometer, to facilitate calculation of $\beta$-radiation attenuation. After shaving $20 \mu \mathrm{m}$ off both sides to remove any externally $\alpha$-doped enamel, the enamel was powdered to 38-76 $\mu \mathrm{m}$ using an agate mortar and pestle, and then split into 4-16 identical aliquots, each weighing approximately $20 \mathrm{mg}$. All aliquots were irradiated with added doses from 0-2560 $\mathrm{G}$ using either a ${ }^{60} \mathrm{Co} y$ source at $185 \mathrm{mGy} / \mathrm{s}$ or a ${ }^{137} \mathrm{Cs}$ source at $39 \mathrm{mGy} / \mathrm{s}$, and annealed at $90{ }^{\circ} \mathrm{C}$ for 3 days to remove all short-lived interference signals created in the irradiation (Skinner et al., 2001).

In the $X$ band, all aliquots were scanned in a JEOL RE1X ESR spectrometer under a 100 $\mathrm{kHz}$ field modulation with an amplitude of $0.1 \mathrm{mT}$ at $2.0 \mathrm{~mW}$ power for teeth. For shells, the power used was $5.0 \mathrm{~mW}$. Spectra were scanned over $10.0 \mathrm{mT}$ centered at $336.0 \mathrm{mT}$, using an 8.0 min. sweep time and a $0.1 \mathrm{~s}$ time constant. Gains were set to balance maximize peak heights and optimum signal-to-noise ratios. Peaks were stored as derivative spectra using EWWIN v. 4.5, and their heights measured without deconvolution (Skinner et al., 2001). For very small fragments aliquots were reirradiated as needed after ESR measurements. This irradiation ramping procedure was repeated until at least 12 independent doses were measured for building the growth curves. Information on the ESR spectrum of tooth enamel and the construction of dose response curves can be found in Skinner, 2015.

All associated sediment, and one enamel, dentine, and bone were powdered to $\leq 100$ $\mu \mathrm{m}$ and analyzed by NAA for $\mathrm{U}, \mathrm{Th}$, and $\mathrm{K}$. Other enamels and dentines were analyzed only for U. Sediment results are shown in Table 2. Sample analyses will be discussed with sample results.

\subsection{Data Analysis}

By plotting the peak heights against the added dose, $A_{\Sigma}$ 's and their errors were calculated using VFit assuming a saturating exponential fit with weighting inverse to intensity $\left(1 / I^{2}\right)$. Using Rosy v. 1.4.2, the ages, dose rates, and their errors were calculated, correcting for attenuation due to backscattering, $\beta$ and $\gamma$ but not $\alpha$, radiation, water concentration, mineralogy, density, and thickness for enamel, dentine, cementum, and sediment (Brennan et al., 1997). To calculate the ages, the $\alpha / \gamma$ efficiency factor was set at $0.15 \pm 0.02$ for enamel (Grün, 1989). Rn loss was assumed to be $0.0 \pm 0.0$ vol\%. The initial $U$ activity ratio, $\left({ }^{234} U /{ }^{238} U\right)_{0}$, was set to $1.2 \pm 0.2$, the normal range for this ratio in natural karst waters (Blackwell, 1989). The time-averaged sedimentary water concentration, $W_{\text {sed, }}$ was assumed to be $15 \pm 5 \mathrm{wt} \%$, 
based on estimates of the relative lifetimes of lake and dry environments. The time-averaged cosmic dose (see Table 1 ) was set to: $D_{\text {cos }}(0)=104 \mu \mathrm{Gy} / \mathrm{y}$.

\section{Results}

The GPS co-ordinates for field and sediment samples are given in Table 3. As noted earlier, most samples from Bir Talata area (Loc. Dak006) come from deflated surfaces. An example of the variability that can be found within a single field sample is shown in Table 4 (see Fig. 7 for sampled areas).

\subsection{Snail Hill Results (Loc. Dak348)}

The ages obtained from the Snail Hill (Loc. Dak348) samples are shown in Table 5. The tooth age is consistent with the presence of the Middle Pleistocene lake dated by the Dakhleh Glass event to $>146 \mathrm{ka}$, with unpublished ${ }^{230} \mathrm{Th} /{ }^{234} \mathrm{U}$ datings on Escarpment spring-deposited tufas of $>200 \mathrm{ka}$ (Fig. 2), and with relative archaeological dating. The mollusc dates, however, are considerably younger, and suggest there was a lake or large pond at a later time, when similar sediments were deposited that are now mostly eroded away.

\subsection{ESR results from Bir Talata area (Holocene Loc. Dak006)}

Table 6 presents the results for samples from ESR collection areas at Bir Talata: 1) from the breached artesian vent, (Loc. Dak447N); 2) from the Older Sand Unit on the southwest slope (Loc. Dak445) (OSU); and 3) from the upslope Red Mud lag area (Loc. Dak446) (RML) (Fig. 7). Additional samples are still being studied but are unlikely to change the conclusions herein in any significant way. Determining sediment dose rates for samples from deflated surfaces requires making assumptions about original burial location. Tooth fragments are sufficiently light that they may have moved after eroding out. Further, samples found on RML may or may not have originally been deposited in the OSU. Fortunately there are not large differences in dose rates between sediment samples from different parts of Loc. Dak006. Figure 9 shows the effect of changing external dose rate assumptions on sample age for a representative sample. Additionally, the internal dose rate is significant for these samples, diminishing the uncertainty introduced by sediment assumptions. Thus, with one exception, dates have been calculated using the average sedimentary dose plus the time-averaged cosmic dose. The exception is Sample PT66C from Field Sample D106. This tooth was intact when found; it fragmented during collection, but could be refitted into a single sample. For that, then, the external dose rate represents the adjacent sediment sample (DAK107) plus the time-averaged cosmic dose. If the average dose were used, the date would be somewhat older (LU $91.3 \pm 8.4 \mathrm{ka}$ ). Enamel $\mathrm{U}$ values in the RML area ranged from 0.18-1.34 ppm. The corresponding dentines range from 2.00-10.37 ppm, with one outlier (Analyzed Sample PT67M) of $41.30 \mathrm{ppm}$. Fragments from the OSU showed higher concentrations. Enamels ranged from 3.65-9.24 ppm; dentines from 65.22$126.05 \mathrm{ppm}$. These differences imply differences in ground water, the source of $U$, between the two geological units.

Molluscs in the backdirt from the breached vent Loc. 447N gave the youngest dates, but these are not from the expected Romano-Byzantine times. The MIS 1 age of $8.4 \pm 0.7 \mathrm{ka}$ is consistent with ${ }^{14} \mathrm{C}$ dates for Masara Unit artefacts elsewhere (McDonald 2003). No cultural units have been identified during MIS 2 in Dakhleh, as yet. 
Contrary to the earlier DOP hypothesis, no Holocene dates were found in samples from either the RML or the OSU. Although dates range widely and overlap between the slope OSU and the upslope RML, there is evidence of temporal difference between the two sampled areas. The OSU ranges from MIS 3 to MIS 6. Some RML fragments are considerably older: dates range from MIS 5 to MIS 17, suggesting that the Red Mud may have been a basal contact bed in Pleistocene deposits. The MIS 12 and 17 dates fall within the time range of the African Upper Acheulian, supporting the typological assignment of rare large bifaces found associated with fossil artesian vents in KPBsn to that complex.

The OSU deposit is probably complex. The small patch of lagged fragments at Field Sample D22 (Fig. 7) in the OSU could have derived from upslope during deposition. Hence, the date ranges in RML and OSU may be a matter of chance in sampling. However, the basal contact date from Field Sample D106 of 84.0 ka (PT66C), and the youngest dated fragment in Field Sample D22 of 48.8 ka (FT74C) constrain the timings of sand unit depositions.

The distribution of dates is shown in Tables 6 and 7. Using LU ages, the largest number come from MIS 5, but samples occur in every stage except MIS 4. Using EU ages, the number in each stage changes, but the overall picture remains the same. While coincidence is possible, the 'gap' in early MIS 6 (133.0 to $154.4 \mathrm{ka}$ ) could reflect biological destruction caused by the Dakhleh meteoritic event (Smith et al., 2009). The adjusted date of 146 ka is accepted for dating the event by planetary scientists (Reimold and Koeberl, 2014).

\section{Conclusions and Implications}

The ESR dates for fauna show that Dakhleh was habitable during a long Pleistocene time range, from MIS 2 to at least MIS 12, even during supposedly 'dry' MIS stages and throughout the MSA time range from 30 to $300 \mathrm{ka}$. The dated teeth from Bir Talata are mainly those of herbivores. Some would have required fresh water daily, and all needed sufficient vegetation. Dakhleh Oasis was a likely Pleistocene refugium for fauna, and possibly for humans, although survival of larger fauna would have been more likely without a human presence. Identified faunal remains indicate that Dakhleh supported an African-type savannah environment. Further, absence of dating does not equal absence of presence; most of the dated materials are those that were obtained from one small area of the oasis where preservation occurred.

However, the lack of any Holocene datings on the Bir Talata upslope teeth indicates that fossilized faunal remains eroding from the Red Mud are Pleistocene in age rather than Holocene as previously published. This suggests that the Holocene Wassif Fauna needs reassessment. Pleistocene bones or teeth were at least partially fossilized and are resistant, even when fragmented. Holocene remains were not fossilized, so that it is likely that any such lying upslope have disintegrated and blown away-e.g., fragmentary 'Neolithic' burials recorded by Churcher in 1979/80 (1981: Fig. 1) were entirely gone by 1997.

At Snail Hill, the discrepancy between the mollusc and tooth datings support previous hypotheses that different lake stages occurred. The dates suggest that: 1) there may be an unconformity separating the upper meters of deposits with the snail horizon from underlying, older lake deposits; or 2) the entire remnant is a younger lake deposit, and the tooth was redeposited from older sediments. Lakebed remnants do exist in the area at a higher elevation 
that could be older. However, the upper horizons are lighter in colour, and, thus, may be younger. Younger deposits may have been formed in a local pond or waterhole that attracted diverse species, possibly including humans.

Concerning MSA occupations, the Bir Talata Unit is now the only cultural unit in Dakhleh with a directly associated chronometric date. The unusual characteristics of the edge treatments are likely task related (Fig. 10), and, in that, bear some resemblance to the 'denticulate Middle Palaeolithic' at Bir Tarfawi (Wendorf et al., 1993:3-4, 571). The assemblage 'fits' neither the Aterian Complex, nor the Nubian Complex. If the few Snail Hill surface artefact finds were associated with nearby Loc. Dak130, that suggests an occupation near a waterhole; and the snail dating may be interpreted as related to the Aterian Complex, Dakhleh Unit. Then, these two archaeological occurrences fall within approximately the same time range, implying that different, penecontemporary human occupations occurred in the oasis that cannot be conventionally placed within any single MSA 'complex'. Long-lived oases undoubtedly attracted diverse human living groups, some who stayed a while, and some who just passed through.

In the Western Desert, lacking caves and shelters, and with few preserved stratified deposits, Pleistocene archaeologists must use surrogates for a chronology based upon 'habitability': 1) the presence of surface water as indicated by dated spring-deposited tufas or other sediments; and 2) evidence for the presence of fauna or flora. ESR dating of freshwater snails provides evidence for both. Dakhleh and Kharga oases are two areas where those surrogates exist together with abundant Pleistocene archaeological remains. Timings of these surrogates can be used to bracket the probable time placements of the typologically/technologically identified archaeological units and complexes, although no argument is made for continuous human habitation. Table 7 shows the bracketing suggested by the new ESR determinations from Bir Talata fauna for the large samples of Pleistocene lithics in Dakhleh Oasis. Table 8 shows the comparisons with Kharga Oasis, where more datings of tufas are directly associated with MSA (and ESA) units.

In the oases, the Middle Stone Age can be clearly subdivided only as 'Older' and 'Younger'. As Caton-Thompson (Caton-Thompson 1952) noted at Kharga in the 1930's, size matters, especially in the case of workshop locations where the size of the raw materials imposes no constraints. She chose 3 attributes for seriation of the MSA: lengths of cores and flakes, talon and flake thickness, and talon treatments. She also reported on the conditions of the lithics. DOP and the Kharga Oasis Prehistory Project have obtained ${ }^{230} \mathrm{Th} /{ }^{234} \mathrm{U}$ determinations on tufas associated with her Kharga MSA sequence (Kleindienst et al. 2008, Smith et al. 2004, 2007), and Caton-Thompson's seriation is correct. (However, we discount her 'transitional' units, 'Levalloiso-Khargan' and 'Acheulio-Acheulian' based only upon lithics redeposited in geological contexts.) ESR dates at Kharga add to evidence of habitability from MIS 2 to MIS 7, and in the earliest Pleistocene (Blackwell et al. 2012; Skinner et al. 2013).

Older MSA is larger in size, and rarely shows any evidence of the Nubian methods of Levallois core reduction; surface aggregates also show a greater degree of abrasion by sand blasting, and of the formation of desert varnish. In the Younger MSA, after ca. 140-145 ka, the discarded flake and core sizes are markedly smaller, and Nubian methods can predominate, although these were not used in all occurrences. The conditions of artefacts show less 
abrasion, and lighter desert varnish. Units belonging to the Khargan Complex, which can only be 'dated' by environmental habitability, are dominated by Levallois flake production. These are regarded as 'Terminal' MSA, although some might assign the lithics to the Later Stone Age. Artefacts are lightly desert varnished, usually with fresher edges. Obviously, the available, directly-related chronometric dating is still unsatisfactory. The evidence for habitability in both oases does provide bracketing for the archaeological units and complexes, allowing comparisons with other areas in Africa.

\section{Acknowledgements}

We thank the Supreme Council for Antiquities of Egypt, and the Chief Inspectors and Inspectors of Antiquities in the New Valley for their patience in assisting prehistoric research. Special thanks are due A. J. Mills, Director of DOP, for his constant encouragement and support. Research on palaeolakes was funded by National Science Foundation (NSF) grant EAR-0447357 and Petroleum Research Fund grant 40650-G8 to Smith. Investigations of the Dakhleh Glass were funded by Geological Society of America (GSA) Eugene Shoemaker Impact Cratering Award to Kieniewicz, and by the Canadian Space Agency Space Science Research Project 05P07. Archaeological and environmental fieldwork in Dakhleh was supported over the years by grants from the Social Sciences and Humanities Research Council of Canada (SSHRC), the Natural Sciences and Engineering Research Council of Canada (NSERC), the National Science Foundation, the National Geographic Society, the University of Toronto, the Dakhleh Trust, and private donors. The National Science Foundation (ILI grant 915111), Williams College, the McMaster University Nuclear Reactor, and the RFK Science Research Institute supported ESR dating. Members of DOP assisted in sample collection. Alice Pidruczny and Jean Johnson, McMaster Nuclear Reactor, performed the NAA. A.C. Montoya, I. Ahmed, J.A. Florentin, and students from the RFK Science Research Institute assisted with some sample preparation. Matthew Limpar, Williams College, prepared several fragments from Loc. Dak006. Uranium series dates shown on Fig. 2, and 4 new ones on Table 8 were run at the laboratory of Prof. Y. Asmerom, University of New Mexico.

\section{References}

Adelsberger, K.A., Smith, J.R., 2010. Paleolandscape and paleoenvironmental interpretation of spring-deposited sediments in Dakhleh Oasis, Western Desert of Egypt. Catena 83, 7-22.

Bagnall, R.S., Davoli, P., Hope, C.A., 2012. The Oasis Papers 6. Proceedings of the Sixth International Conference of the Dakhleh Oasis Project. Oxbow Books, Oxford, 499 pp.

Blackwell, B.A.B., 1989. Laboratory Procendures for ESR Dating of Tooth Enamel. McMaster University Department of Geology, Hamilton, Ontario, $289 \mathrm{pp}$.

Blackwell, B.A.B., Montoya, A., Blickstein, J.I.B., Skinner, A.R., Pappu, S., Gunnell, Y., Taieb, M., Kumar, A., Lundburg, J., 2007. ESR Analyses for Teeth from the Open-Air Site at Attirampakkam, India: Clues to Complex U Uptake and Paleoenvironmental Change. Radiation Measurements 42, 1243-1249. 
Blackwell, B.A.B., Skinner, A.R., Mashriqi, F., Deely, A.E., Long, R.A., Gong, J.J.J., Kleindienst, M.R. \& Smith, J.R.m 2012. Challenges in constraining pluvial events and hominin activity: Examples of ESR dating molluscs from the Western Desert, Egypt. Quaternary Geochronology, 10, 430-435.

Bowen, G.E., Hope, C.A., 2003. The Oasis Papers 3. Proceedings of the Third International Conference of the Dakhleh Oasis Project. Oxbow Books, Oxford, $392 \mathrm{pp}$.

Brennan, B.J., Schwarcz, H.P., Rink, W.J., 1997. Simulation of the gamma radiation field in lumpy environments. Radiation Measurements 27, 299-305.

Brookes, I.A., 1986. Quaternary geology and geomorphology of the Dakhleh Oasis region and its environs, south-central Egypt. Reconnaissance findings. York University, Department of Geography, Discussion Paper Series 32, 90 pp.

Brookes, I.A., 1989. Above the salt: sediment accretion and irrigation agriculture in an Egyptian oasis. Journal of Arid Environments 17, 335-348.

Brookes, I.A., 1993. Geomorphology and Quaternary geology of the Dakhla Oasis region, Egypt. Quaternary Science Reviews 12, 529-552.

Caton-Thompson, G., 1952. Kharga Oasis in Prehistory. Athlone Press, London.

Churcher, C.S., 1980. Dakhleh Oasis Project. Preliminary observations on the geology and vertebrate palaeontology of northwestern Dakhleh Oasis. Journal of the Society for the Study of Egyptian Antiquities 10, 370-396.

Churcher, C.S., 1981. Dakhleh Oasis Project. Geology and palaeontology: interim report on the 1980 field season. Journal of the Society for the Study of Egyptian Antiquities 11, 194212.

Churcher, C.S., 1982. Dakhleh Oasis Project. Geology and palaeontology: interim report on the 1981 field season. Journal of the Society for the Study of Egyptian Antiquities 12, 108114.

Churcher, C.S., 1983. Dakhleh Oasis Project. Palaeontology: Interim report on the 1982 field season. Journal of the Society for the Study of Egyptian Antiquities 13, 178-187.

Churcher, C.S., 1999a. Holocene faunas of Dakhleh Oasis. In: Churcher, C.S., Mills, A.J. (Eds.), Reports from the Survey of Dakhleh Oasis, Western Desert of Egypt, 1977-1987. Oxbow Books, Oxford, pp. 133-151.

Churcher, C.S., 1999b. The Neolithic fauna from archaeological contexts in Dakhleh Oasis, Egypt. Archaeozoologia 10, 47-54.

Churcher, C.S., Kleindienst, M.R., 1999. Mid-Pleistocene fauna from Dakhleh Oasis, Western Desert of Egypt. Journal of Vertebrate Paleontology 19, Abstracts of Papers, 38A.

Churcher, C.S., Kleindienst, M.R. n.d. Great Lakes in the Dakhleh Oasis: Mid-Pleistocene Freshwater Lakes in the Dakhleh Oasis Depressions, Western Desert, Egypt. In: Kaper, O. (Ed.), The Oasis Papers 4. Proceedings of the Fourth International Conference of the Dakhleh Oasis Project, Oxbow Books, Oxford (in press).

Churcher, C.S., Kleindienst, M.R., Schwarcz, H.P., 1999. Faunal remains from a Middle Pleistocene lacustrine marl in Dakhleh Oasis, Egypt: palaeoenvironmental reconstructions. Palaeogeography, Palaeoclimatology, Palaeoecology 154, 301-312.

Churcher, C.S., Kleindienst, M.R., Wiseman, M.F., McDonald, M.M.A., 2008. The Quaternary faunas of Dakhleh Oasis, Western Desert of Egypt. In Wiseman, M.F. (Ed.), The Oasis Papers 2. The Second International Conference of the Dakhleh Oasis Project, Oxbow Books, Oxford, 1-24. 
Churcher, C.S., Mills, A.J., 1999. Reports from the Survey of Dakhleh Oasis, Western Desert of Egypt, 1977-1987. Oxbow Books, Oxford, 271 pp.

Deely, A.E., Blackwell, B.A.B., Mylroie, J.E., Carew, J.L., Blickstein, J.I.B., Skinner, A.R., 2011. Testing cosmic dose rate models for ESR: Dating corals and molluscs on San Salvador, Bahamas. Radiation Measurements 46, 853-859.

Ebraheem, A.M., Riad, S., Wycisk, P., Sefelnasr, A.M., 2004. A local-scale groundwater flow model for groundwater resources management in Dakhla Oasis, SW Egypt. Hydrogeology Journal 12, 714-722.

Foley, R.A., Maíllo-Fernández, J.M., Lahr, M.M., 2013. The Middle Stone Age of the Central Sahara: Biogeographical opportunities and technological strategies in later human evolution. Quaternary International 300, 153-170.

Gossel, W., Ebraheem, A.M., Wycisk, P., 2004. A very large scale GIS-based groundwater flow model for the Nubian sandstone aquifer in Eastern Sahara (Egypt, northern Sudan and eastern Libya). Hydrogeology Journal 12, 698-713.

Grün, R., 1989. Electron spin resonance (ESR) dating. Quaternary International 1, 65-109.

Grün, R., McDermott, F., 1994. Open system modeling for U-series and ESR dating of teeth. Quaternary Science Reviews 13:121-125.

Hawkins, A.L., 2001. Getting a Handle on Tangs: The Aterian of the Western Desert of Egypt. Ph.D. Thesis, Department of Anthropology, University of Toronto, 698 pp.

Hermina, M., 1990. The surroundings of Kharga, Dakhla and Farafra oases. In: Said, R. (Ed.), The Geology of Egypt. A.A. Balkema, Rotterdam/Brookfield, pp.259-292.

Hope, C.A., Bowen, G.E., 2002. Dakhleh Oasis Project: Preliminary reports on the 1994-1995 to 1998-1999 field seasons. Oxbow Books, Oxford, 360 pp.

Hope, C.A., Mills, A.J., 1999. Dakhleh Oasis Project: Preliminary reports on the 1992-1993 and 1994 field seasons. Oxbow Books, Oxford, 103 pp.

Kato, H., Kimura, R., Elbeih, S.F., Iwasaki, E., Zaghioul, E.A., 2012. Land use change and crop rotaton analysis of a govenment well district in Rashda village -- Dakhla Oasis, Egypt based on satellite data. The Egyptian Journal of Remote Sensing and Space Sciences 15, 185-195.

Kieniewicz, J.M., 2007. Pleistocene Pluvial Lakes of the Western Desert of Egypt: Paleoclimate, Paleohydrology, and Paleolandscape Reconstructions, Ph.D. Thesis, Department of Earth and Planetary Sciences. Washington University, St. Louis, Missouri, 270pp.

Kieniewicz, J.M., Smith, J.R., 2009. Paleoenvironmental reconstruction and water balance of a mid-Pleistocene pluvial lake, Dakhleh oasis, Egypt. Bulletin of the Geological Society of America 121, 1154-1171.

Kleindienst, M.R., 1999. Pleistocene archaeology and geoarchaeology: a status report. In: Churcher, C.S., Mills, A.J. (Eds.), Reports from the Survey of Dakhleh Oasis, Western Desert of Egypt, 1977-1987. Oxbow Books, Oxford, pp. 83-108.

Kleindienst, M.R., 2003. Strategies for studying Pleistocene archaeology based upon surface evidence: first characterisation of an older Middle Stone Age unit, Dakhleh Oasis, Western Desert, Egypt. In: Bowen, G.E., Hope, C.A. (Eds.), The Oasis Papers 3. Proceedings of the Third International Conference of the Dakhleh Oasis Project. Oxbow Books, Oxford, pp. 1-42. 
Kleindienst, M.R., Churcher, C.S., Churcher, B., Schwarcz, H.P., Haldemann, A.F.C., Smith, J.R., Osinski, G.R., 2006. Geoarchaeological investigations in Dakhleh Oasis, Western Desert, Egypt: Did a meteorite strike Dakhleh during the time of Middle Stone Age occupations? Archaeology of Early Northeastern Africa 9, 437-447.

Kleindienst, M.R., Churcher, C.S., McDonald, M.M.A., Schwarcz, H.P., 1999. Geography, geology, geochronology, and geoarchaeology of the Dakhleh Oasis Region: An Interim Report. In: Churcher, C.S., Mills, A.J. (Eds.), Reports from the Survey of Dakhleh Oasis, Western Desert of Egypt, 1977-1987. Oxbow Books, Oxford, pp. 1-54.

Kleindienst, M.R., Schwarcz, H.P., Nicoll, K., Churcher, C.S., Frizano, J., Gigengack, R.W., Wiseman, M.F., 2008. Water in the desert: First report on Uranium-series dating of Caton-Thompson's and Gardner's "classic" Pleistocene sequence at Refuf Pass, Kharga Oasis. In: Wiseman, M.F. (Ed.), The Oasis Papers 2. Proceedings of the Second International Conference of the Dakhleh Oasis Project. Oxbow Books, Oxford, pp. 25-54.

Larrasoaña, J.C., 2012. A Northeast Saharan perspective on environmental variability in North Africa and its implications for modern human origins. In: Hublin, J.-J., McPherron, S.P. (Eds.), Modern Origins. A North African Perspective. Springer, Dordrecht, pp. 19-33.

Larrasoaña, J.C., Roberts, A.P., Rohling, E.J., 2013. Dynamics of Green Sahara Periods and their role in Hominin evolution. PLOS ONE 8. DOI:10.1371/journal.pone.0078814.

Marlow, M., Mills, A.J., 2000. The Oasis Papers. Proceedings of the First International Symposium of the Dakhleh Oasis Project. Oxbow Books, Oxford.

McDonald, M.M.A., 1980. Dakhleh Oasis Project. Preliminary report on lithic industries in the Dakhleh Oasis. Journal of the Society for the Study of Egyptian Antiquities 10, 315-329.

McDonald, M.M.A., 2001. The Late Prehistoric radiocarbon chronology for Dakhleh Oasis within the wider environmental and cultural setting of the Egyptian Western Desert. In: Marlow, C.A., Mills, A.J. (Eds.), The Oasis Papers. Proceedings of the First Conference of the Dakhleh Oasis Project. Oxbow Books, Oxford, pp. 26-42.

McDonald, M.M.A., 2003. The early Holocene Masara A and Masara C cultural subunits of Dakhleh Oasis , Egypt, within a wider cultural setting. In: Bowen, G.E., Hope, C.A. (Eds.), The Oasis Papers 3. Proceedings of the Third International Conference of the Dakhleh Oasis Project. Oxbow Books, Oxford, pp. 43-69.

McDonald, M.M.A., 2008. Emerging social complexity in the Mid-Holocene Egyptian Western Desert: Site 270 and its neighbors in south-eastern Dakhleh Oasis. In: Wiseman, M.F. (Ed.), The Oasis Papers 2. The Second International Conference of the Dakhleh Oasis Project. Oxbow Books, Oxford, pp. 83-106.

McDonald, M.M.A., 2009. Increased sedentism in the central oasesof the Egyptian Western Desert in the early to mid-Holocene: evidence from the periphery. African Archaeological Review 26, 3-43.

Osinski, G.R., Kieniewicz, J., Smith, J.R., Boslough, M.B., Eccleston, M., Schwarcz, H.P., Kleindienst, M.R., Haldemann, A.F.C., Churcher, C.S., 2008. The Dakhleh Glass: Product of an impact airburst or cratering event in the Western Desert of Egypt? Meteoritics \& Planetary Science 43, 2089-2107.

Osinski, G.R., Schwarcz, H., P., Smith, J., R,, Kleindienst, M.R., Haldemann, A.F.C., Churcher, C.S., 2007. Evidence for a $200-100$ ka meteorite impact in the Western Desert of Egypt. Earth and Planetary Science Letters 253, 378-388. 
Porat, N., Schwarcz, H.P., 1994. ESR Dating of Tooth Enamel: A Universal Growth Curve. In: Corrucini, R.S., Ciochon, R.L. (Eds.), Integrative Paths to the Past, Paleoanthropological Advances in Honor of F. Clark Howell, Prentice Hall, Englewood, New Jersey, pp. 521530.

Reimold, W.U., Koeberl, C., 2014. Impact structures in Africa: A review. Journal of African Earth Sciences 93, 57-175.

Renne, P.R., Schwarcz, H.P., Kleindienst, M.R., Osinski, G.R., Donovan, J.J., 2010. Age of the Dakhleh impact event and implications for Middle Stone Age archeology in the Western Desert of Egypt. Earth and Planetary Science Letters 291, 201-206.

Rink, W.J., 1997. Electron spin resonance (ESR) dating and ESR applications in quaternary science and archaeometry. Radiation Measurements 27, 975-1025.

Schwarcz, H.P., Szkudlarek, R., Kleindienst, M.R., Evenesen, N., 2008. Fire in the desert: the occurrence of a high-Ca silicate glass near the Dakhleh Oasis, Egypt. In: Wiseman, M.F. (Ed.), The Oasis Papers 2. Proceedings of the Second International Conference of the Dakhleh Oasis Project. Oxbow Books, Oxford, pp. 55-71.

Sefelnasr, A., Gossel, W., Wycisk, P., 2014. Three-dmensional groundwater flow modeling approach for the groundwater management options for the Dakhla oasis, Western Desert, Egypt. Environmental Earth Sciences 72, 1227-1241.

Skinner, A.R. 2015. General Principles of Electron Spin Resonance (ESR) Dating. In: Rink,W.J., Thompson, J.W. (Eds), Encyclopedia of Scientific Dating Methods. Springer Reference, Dordrecht, pp. 246-255.

Skinner, A.R., Blackwell, B.A.B., Chasteen, N.D., Shao, J., Min, S.S., 2000. Improvements in dating tooth enamel by ESR. Applied Radiation and Isotopes 52:1337-1344.

Skinner, A.R., Chasteen, M.D., Shao, J., Blackwell, B.A.B., 2001. Q-band studies of the ESR signal in tooth enamel. Quaternary Science Reviews 20, 1027-1030.

Skinner, A.R., Blackwell, B.A.B., Kleindienst, M.R., Smith, J.R., Kieniewicz, J.M., Adelsberger, K.A., Churcher, C.S., Deely, A.E., Mashiriqi, F., Spiller, K.V., Blickstein, J.I.B., Gong, J.J.J. and Long, R.A. 2013. Reconstructing paleoenvironments in the Western Desert, Egypt: ESR dating freshwater molluscs from Kharga Oasis. In: Armitage, R.A., Burton, J.H. (Eds.), Archaeological Chemistry VIII, ACS Symposium Series. American Chemical Society, Washington, D.C., pp. 321-364.

Smith, J.R., Giegengack, R., Schwarcz, H.P., McDonald, M.A.A., Kleindienst, M.R., Hawkins, A.L. \& Churcher, C.S. 2004. Reconstructing Pleistocene pluvial environments and occupation through the stratigraphy and geochronology of fossil-spring tufas, Kharga Oasis, Egypt. Geoarchaeology, 19, 407-439.

Smith, J.R., Hawkins, A.L., Asmerom, Y., Polyak, V., Giegengack, R., 2007. New age constraints on the Middle Stone Age occupations of Kharga Oasis, Western Desert, Egypt. Journal of Human Evolution 52, 690-701.

Smith, J.R., Kleindienst, M.R., Schwarcz, H.P., Churcher, C.S., Kieniewicz, J.M., Osinski, G.R., Haldemann, A.F.C., 2009. Potential consequences of a Mid-Pleistocene impact event for the Middle Stone Age occupants of Dakhleh Oasis, Western Desert, Egypt. Quaternary International 195, 138-149.

Smith, J.R., 2012. Spatial and temporal variation in the nature of Pleistocene pluvial phase environments across North Africa. In: Hublin, J.-J., McPherron, S.P. (Eds.), Modern Origins. A North African Perspective. Springer, Dordrecht, pp. 35-47. 
Thanheiser, U., 2008. Times of Change. Environment and Subsistence in Late Prehistoric Dakhleh, Egypt. Doctoral Thesis, University of Vienna, Vienna.

Thurston, H., 2003. Island of the Blessed. The Secrets of Egypt's Everlasting Oasis. Doubleday Canada, Toronto.

Vose, R.S., Schmoyer, R.L., Peterson, T.C., Heim, R., Karl, T.R., Eischeid, J., 1992. The Global Historical Climatology Network: Long-Term Monthly Temperature, Precipitation, Sea Level Pressure and Station Pressure Data Carbon Dioxide Information Analysis Center. Oak Ridge National Laboratory, Oak Ridge, Tennessee.

Wendorf, F., Schild, R., Close, A.E., Associates, a., 1993. Egypt during the Last Interglacial. The Middle Paleolithic of Bir Tarfawi and Bir Sahara East. Plenum Press, New York, London.

Wiseman, M.F., 2008. The Oasis Papers 2. Proceedings of the Second International Conference of the Dakhleh Oasis Project. Oxbow Books, Oxford, 160 pp.

Zaghloul, E.A., Hassan, S.M., Bahy El-Dein, A.M., Elbeih, S.F., 2013. Detection of ancient irrigation canals of Deir El-Hagar playa, Dakhla Oasis, Egypt, using Egyptsat-1 data. The Egyptian Journal of Remote Sensing and Space Science 16, 153-161. 


\section{Dak Figure Captions}

Figure 1. Dakhleh Oasis Region, Western Desert, Egypt, showing two modern basins (lighter shading) separated by the Tawil Anticline sandstone ridge, and main settlements. Elevations are given in meters above sea level (a.s.l.). The two shallow basins to the east at higher elevations held shallow Late Pleistocene palaeolakes, but have not been thoroughly surveyed for Pleistocene evidence. Dune streak is dark shaded.

Figure 2. Northeastern Dakhleh Oasis. Schematic section, showing geological formations, geomorphic surfaces, and postulated Palaeolake Balat level at $160 \mathrm{~m}$ a.s.I. OMSA, Older Middle Stone Age artefacts in situ in the Calcareous Silty Sediments (CSS) Member, Lake Teneida Fm. Some Dakhleh Glass ( $\sim 46 \mathrm{ka}$ ) is found lagged at $159 \mathrm{~m}$ a.s.I. The ${ }^{230} \mathrm{Th} /{ }^{234} \mathrm{U}$ date on a tufa terrace overlying a P-I colluvial surface is located further west on Battikh Promontory. The dated tufa boulder gives a limiting date for the formation of the P-II gravels in this area.

Figure 3. Dakhleh Oasis: areas of Middle Pleistocene palaeolakes projected onto the modern topography. Elevations given in meters a.s.l., with shading: lighter $=\leq 150-160 \mathrm{~m}$ a.s.l.; darker $=\leq 140 \mathrm{~m}$ a.s.l.; darkest $=\leq 130 \mathrm{~m}$ a.s.l. Palaeolake Balat would have overtopped the Tawil Anticline ridge, from ca. 140 to $\geq 160 \mathrm{~m}$ a.s.l. Legend: TT, remnants of tufa terraces on the Libyan Escarpment face; TB, tufa boulders displaced into colluvium or alluvium; 006, etc., numbered archaeological localities noted in text.

Figure 4. Snail Hill, Loc. Dak348. Left: distant view of remnant on southeastern rim of the eastern Dakhleh basin, looking south-southeast (arrow). Small remnant of Mut Fm. capped by CSS in right foreground, and abandoned wellheads in center ground below the Taref Fm. sandstone rim. Right: looking east-southeast from Loc. Dak130 in left foreground on eroded Taref Fm. sandstone bench. ESR dated snail lens on south end of northern knoll (arrow).

Figure 5. Sketch map of Snail Hill area, on southeastern rim of the eastern Dakhleh basin, adjacent to Loc. Dak130 (L.) with lagged, abraded Aterian Complex artefacts on eroded Taref Formation sandstone (sst.). ESR Samples: S, snail shells in situ in CSS (Field Sample D27 and D28, Analyzed Samples RM61A, RM68); T, tooth in situ in CSS (Field Sample 30, Analyzed Sample FT73).

Figure 6. Bir Talata area, Loc. Dak006: Left: upslope area, looking west to Gebel Edmonstone over lag resting on Red Mud surface, seen from blowout area, with overlying isolated yardangs of Romano-Byzantine irrigation deposits. Dark line of breached fossil artesian vents and irrigation canals in distance. Right: looking south, with blowout in lower left foreground, and figure for scale. Stony lag on Red Mud surface with the overlying irrigation deposit yardangs; modern dune in left background. Yardangs are 'aerodynamic' desert landforms shaped by wind and sand blast; their orientations reflect prevailing wind directions.

Figure 7. Sketch map of Bir Talata area, western Dakhleh Oasis, Loc. Dak006, compiled from field notes and publications: topography and dune locations as shown on Google Earth in 2013. Legend (L. = Loc.): BV, breached fossil artesian vent leading to irrigation canal (dark 
mask); EV, older fossil artesian vents eroded to low rim remnants; M, Loc. Dak447S, Masara Unit artefacts in Romano-Byzantine backdirt; Loc. 445, area at foot of slope deflated to sandstone contact, exposing YMSA artefacts. Loc. 446, upslope area of Red Mud, with yardangs (dark shaded) overlying surface lag; TY, irrigation deposit yardang with cast of small tree; AY, yardang with drawn section; Hmst, hammerstone/anvil with bone, in situ; B, Loc. Dak006, Bashendi Unit concentrations on surface; B+, mixed components, Bashendi Unit and later; OK, Old Kingdom sherdage on surface; 102 etc., ESR Field Samples. Basal, exposed sedimentary unit is Taref Formation sandstone (sst.).

Figure 8. Bir Talata, Loc. Dak006, section at Ass yardang (Fig. 7, AY) in 1979-80, generalized and reinterpreted; yardang now mainly destroyed by aeolian erosion. Irrigation deposits: poorly stratified sands and silts with pea gravels. 'Older Sand Unit': silty sand, with leg bones of Equus assinus exposed on surface (OSU). 'Red Mud': claystones with clasts eroding into lag on modern surface (RML). Basal red claystones: possibly in situ Cretaceous Mut Fm. Taref Fm. sandstone at base. Surface lag: on buried Red Mud surfaces, and on modern surface (arrows). ESR dates from the Older Sand Unit (OSU) range from MIS 3 to MIS 6; those from the Red Mud (RML) surface lag range from MIS 5 to MIS 17 (see Fig. 7 for Field Sample numbers).

Figure 9. Effect of changing assumptions about external dose rate on derived ages. Calculated external dose: $984 \mu \mathrm{Gy} / \mathrm{a}$. Within 10-20\% change in external dose rate, the change in age does not exceed the experimental uncertainty.

Figure 10 Some Bir Talata Unit pieces from the Older Sand Unit (OSU) at Locality Dak445: a) side scraper with jagged edge, chalcedony; b) side scraper with jagged edge, quartzite; c) side scraper with notched edge, Tarawan chert; d) small biface, Tarawan chert; e) end scraper on thick flake, notched edge, white chert; f) pointed Levallois flake, Tarawan chert, with proximal left corner broken; g) small pointed tool, Tarawan chert, tip broken. All in fresh condition except (f), which is lightly abraded; fresh edge damage on left lateral (double patinated) suggests that piece was recycled. Surface patinations yellow-tan in color and iron stained. 


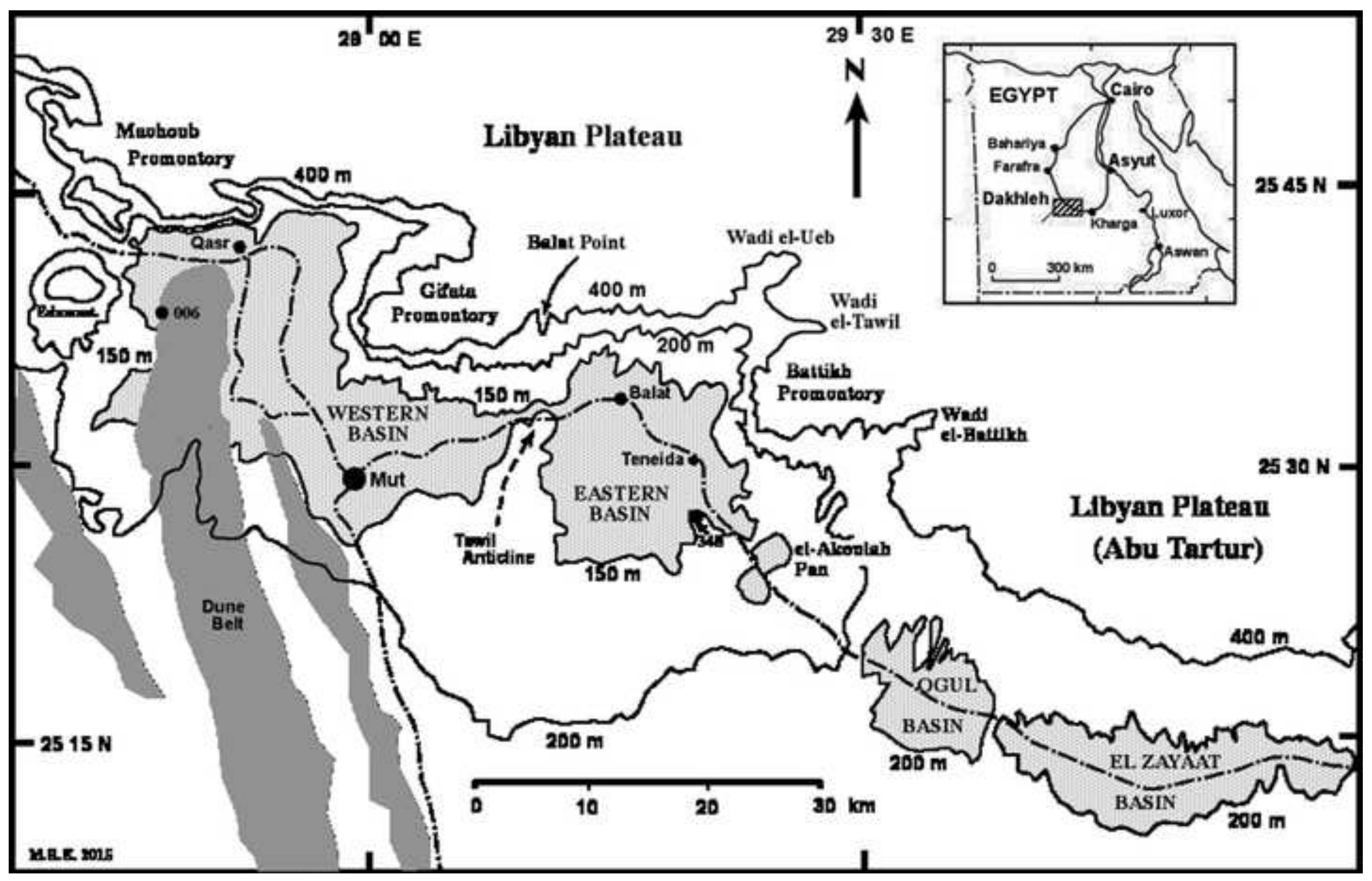


Libyan Plateau

Garra \& Kurkur Fms.

limestones

Dakhla Fm. shaies

P I, Tufa Terrace $211+1-2.4 \mathrm{ka}$ slumped colluvium

Overwegi Bed

Dakhla Fm. shales
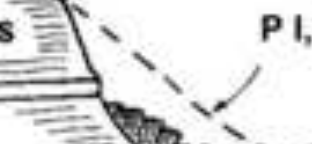

1 PII

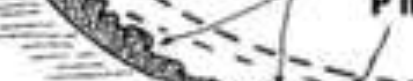

Duwi Fm. phosphorites
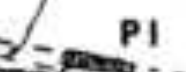

Pll gravels

$214+/-4$ ka PI

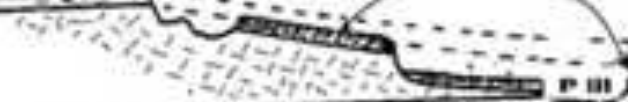

Mut Fm. claystones

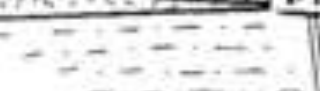

$-1-2=$

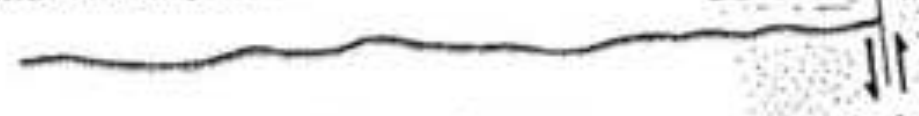

Taref $\mathrm{Fm}$. sandstones

fault

Palaeolake Balat 


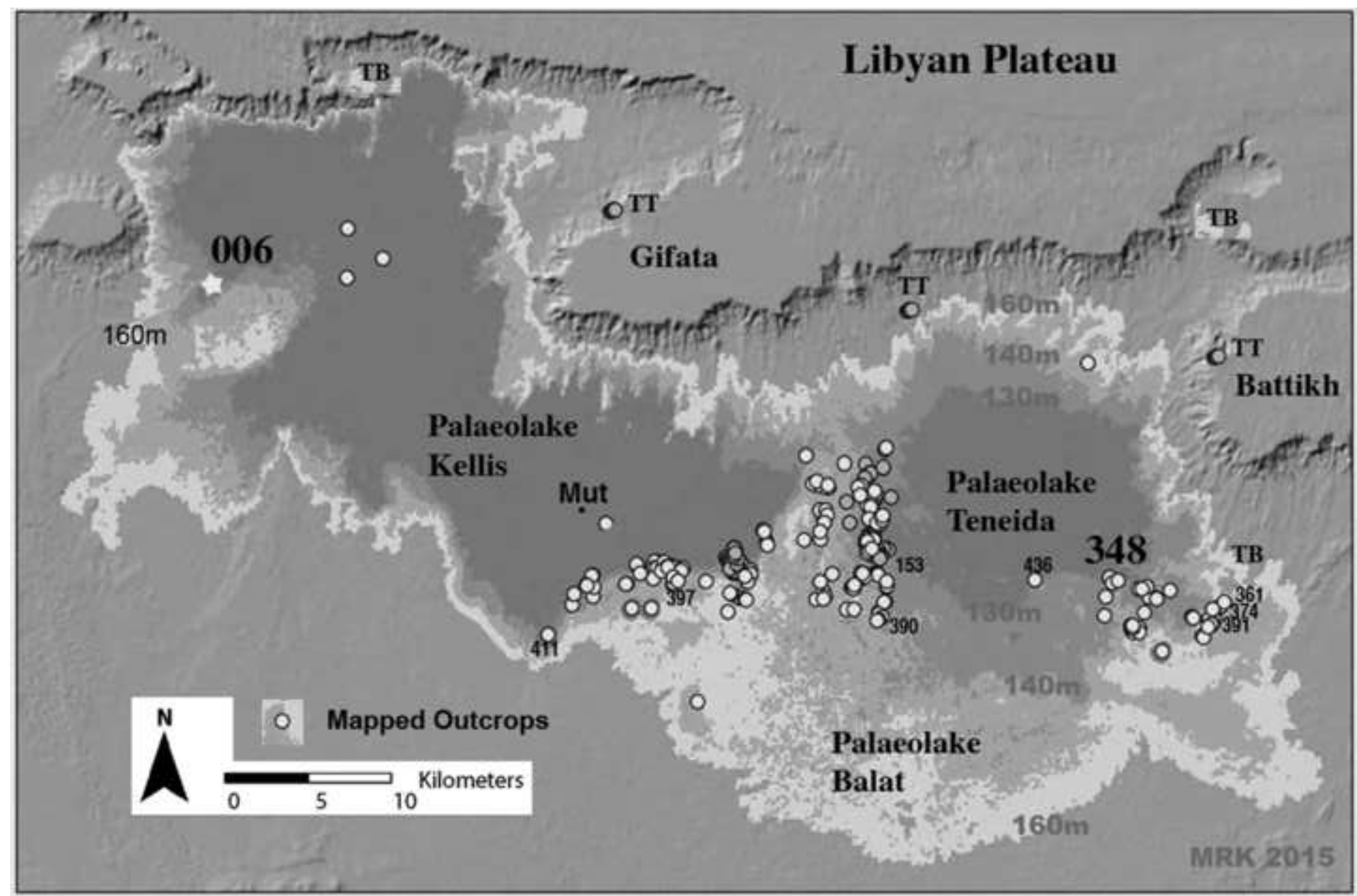




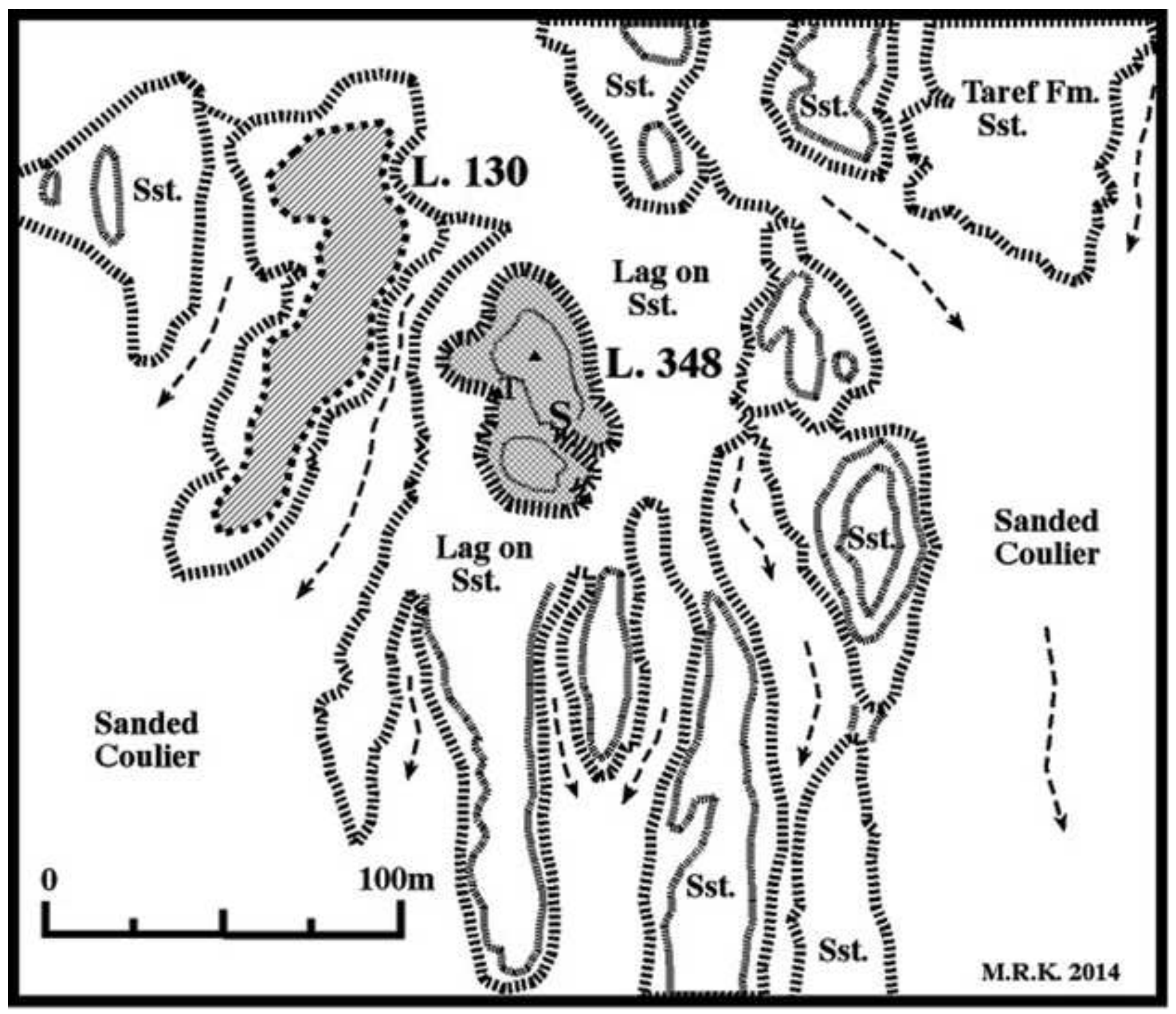



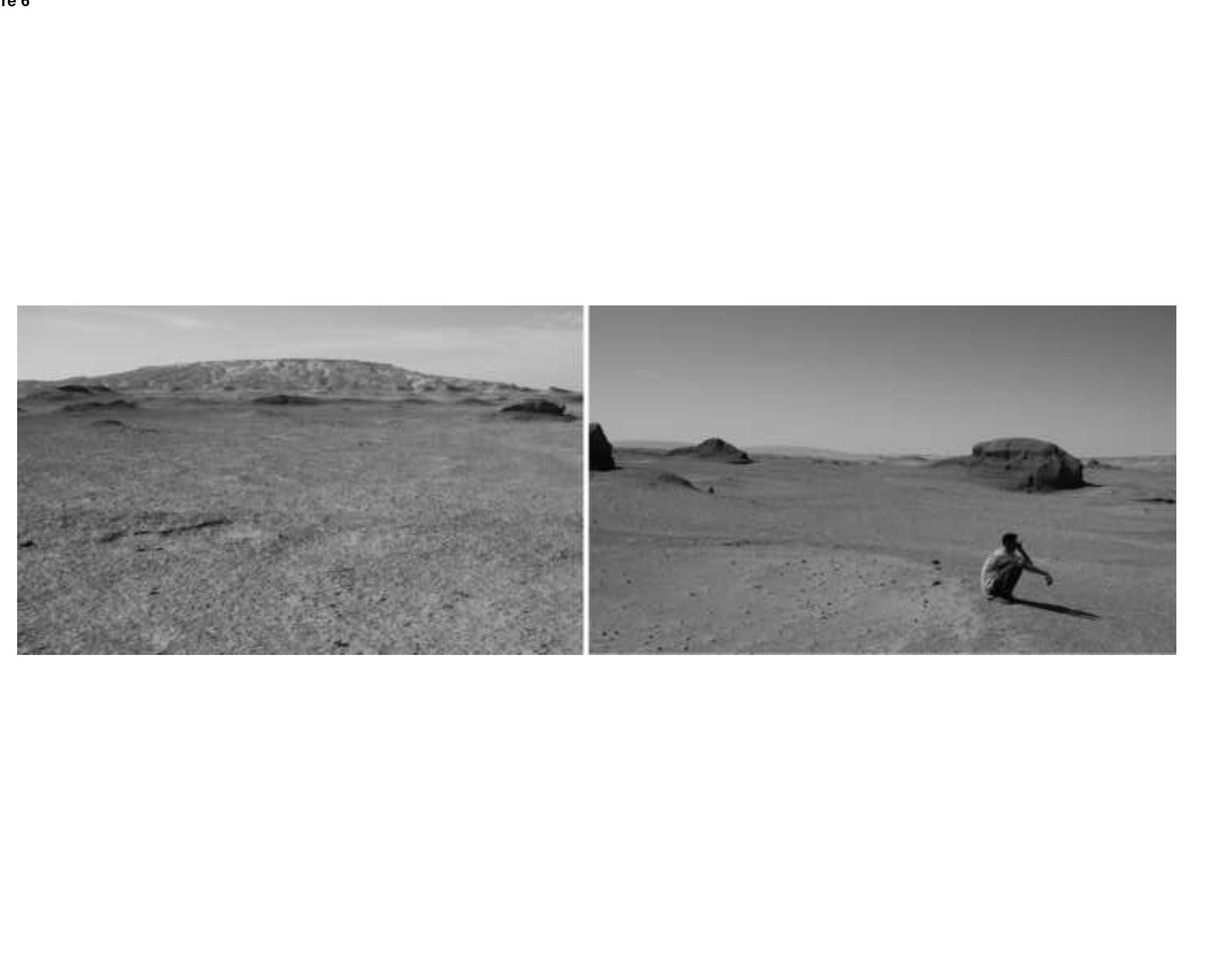

Figure 6

Figure

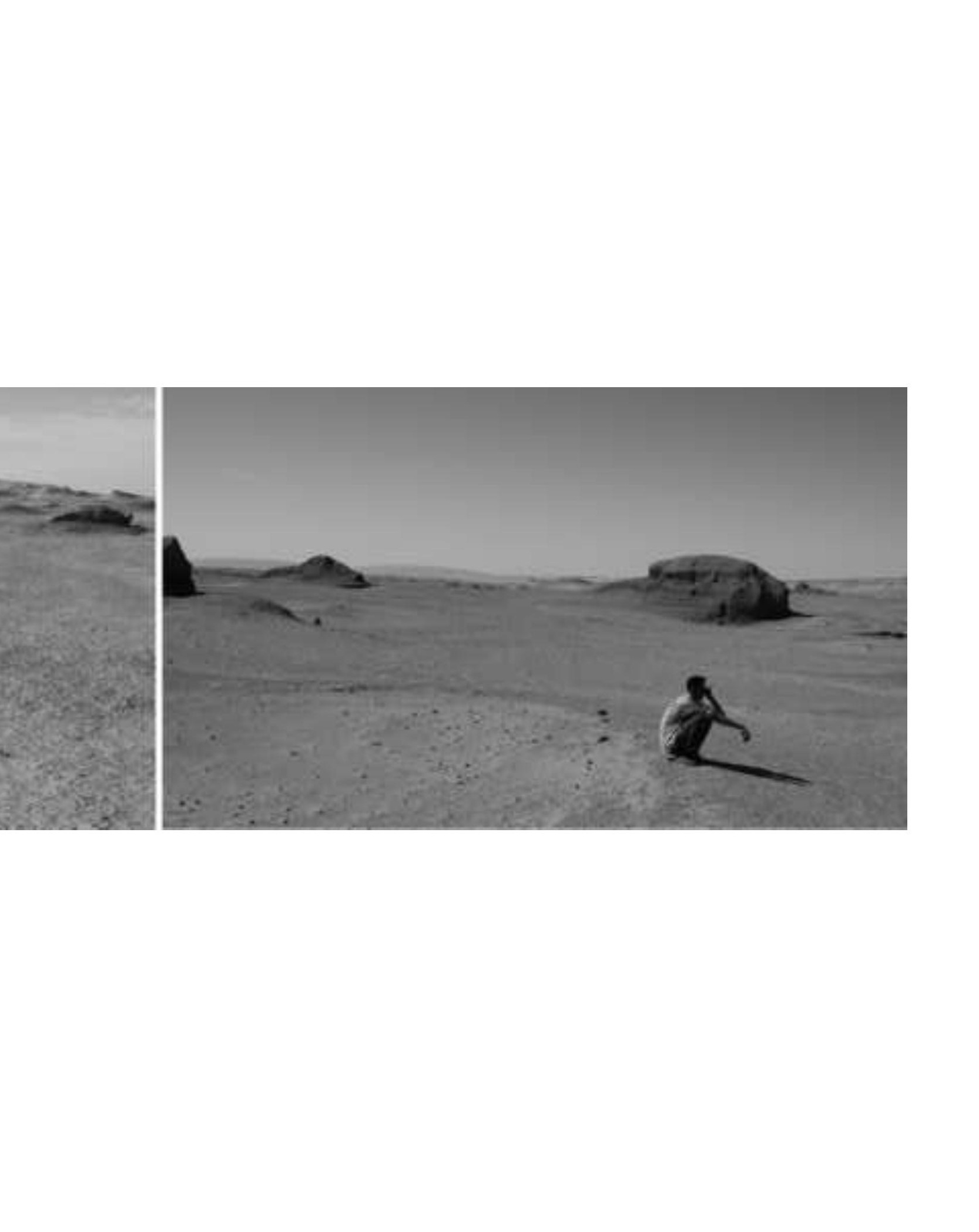

6
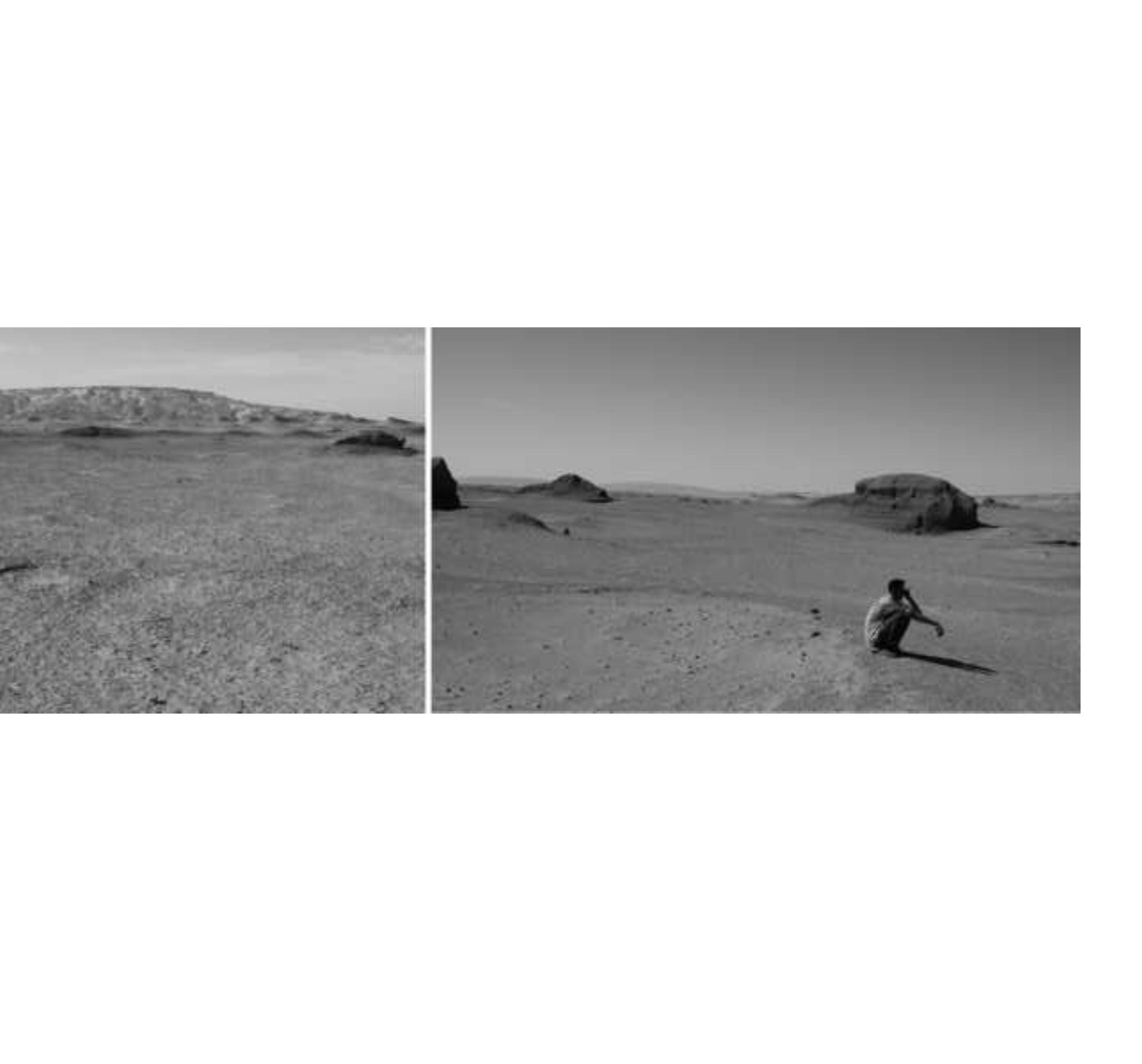


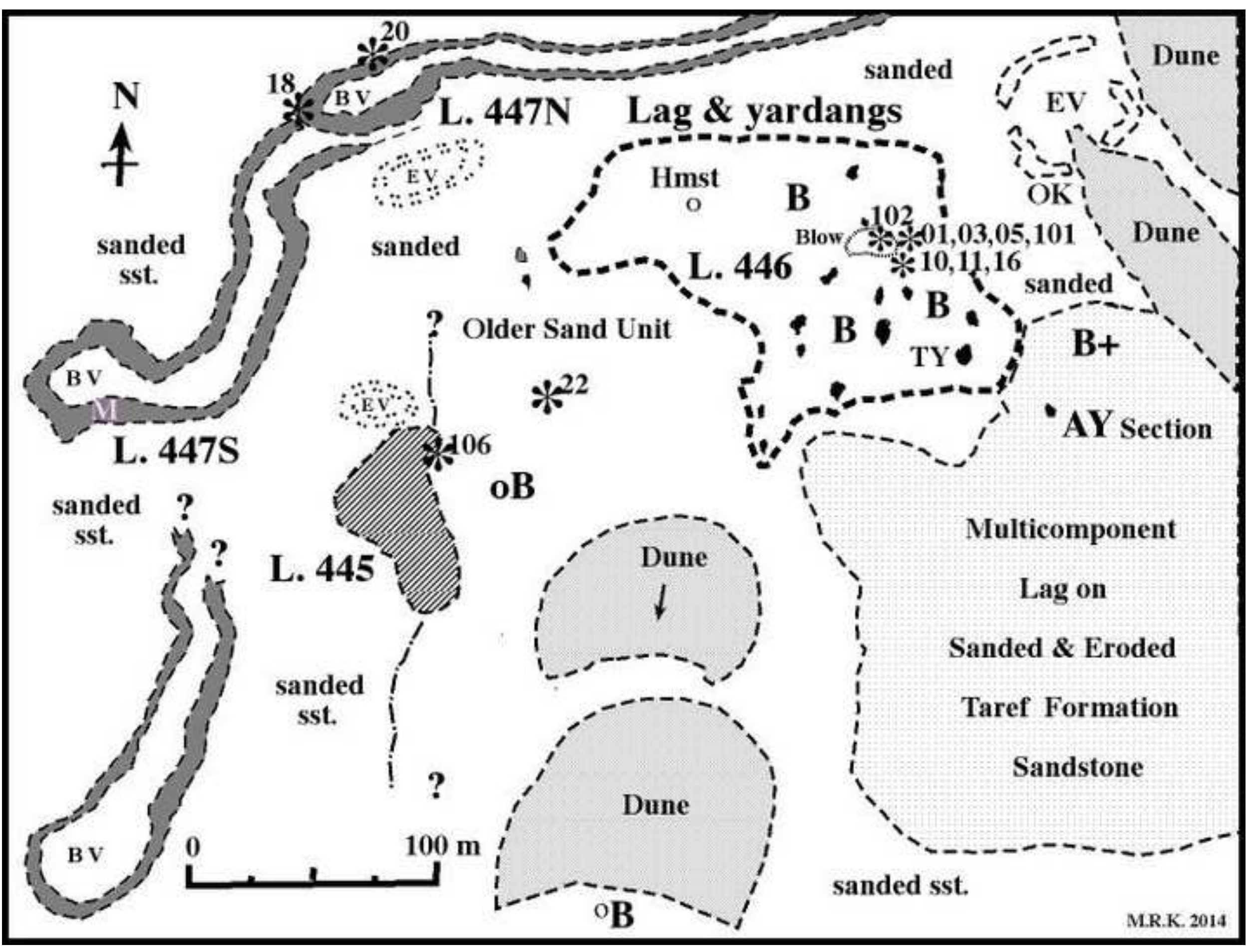




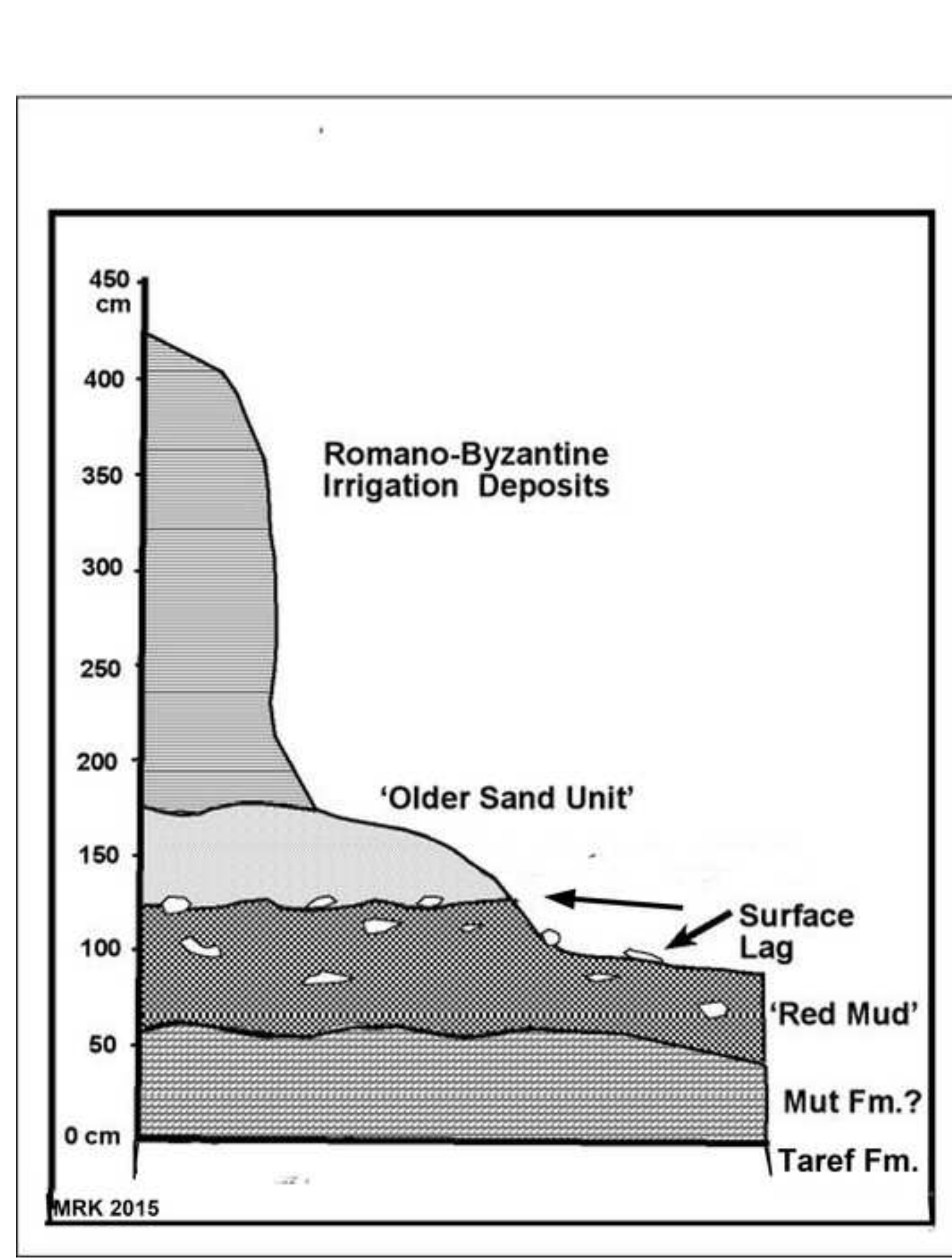

Figure 8

8

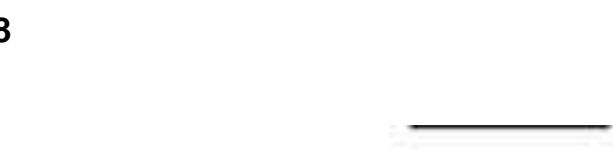




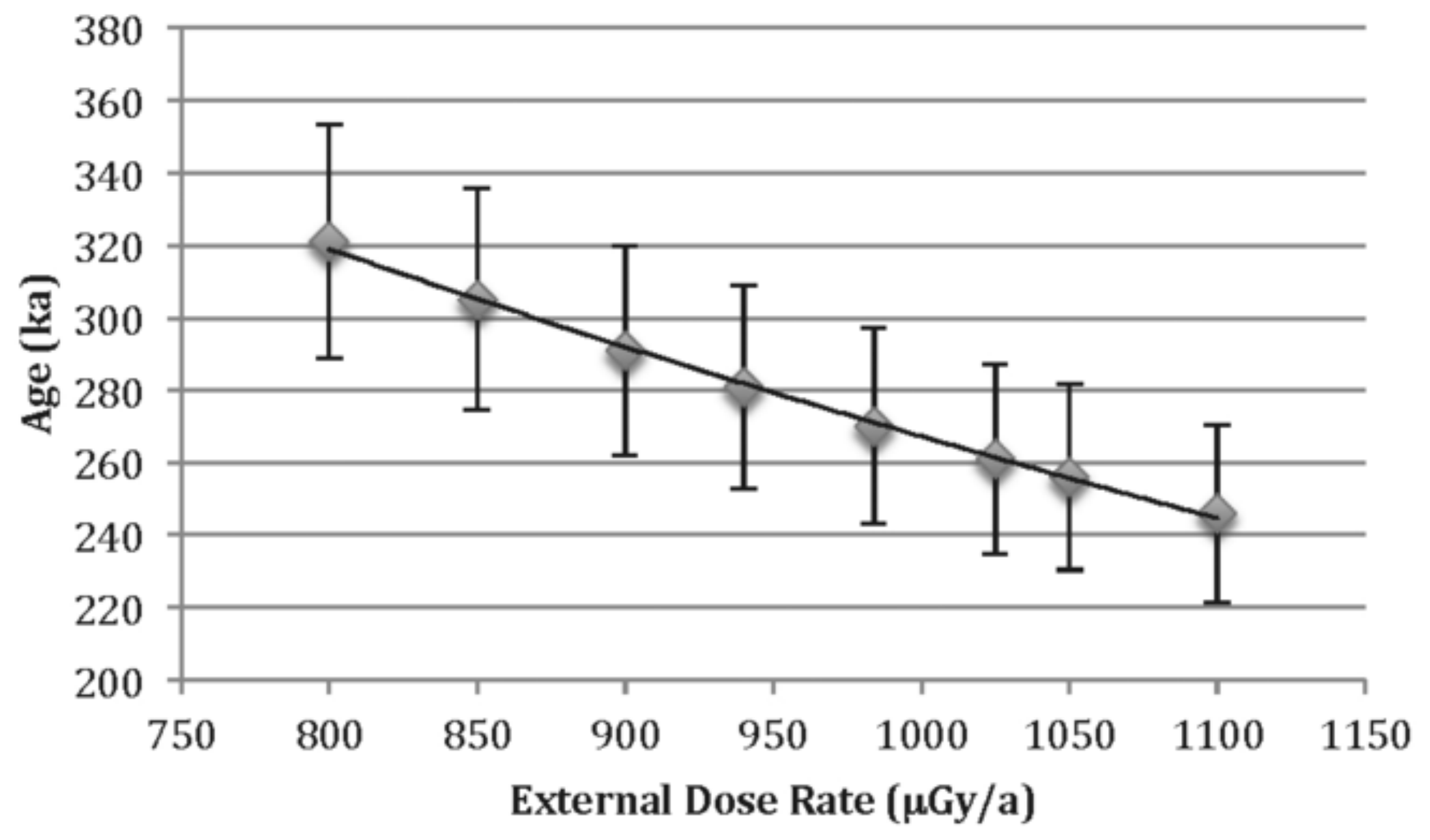


Figure 10
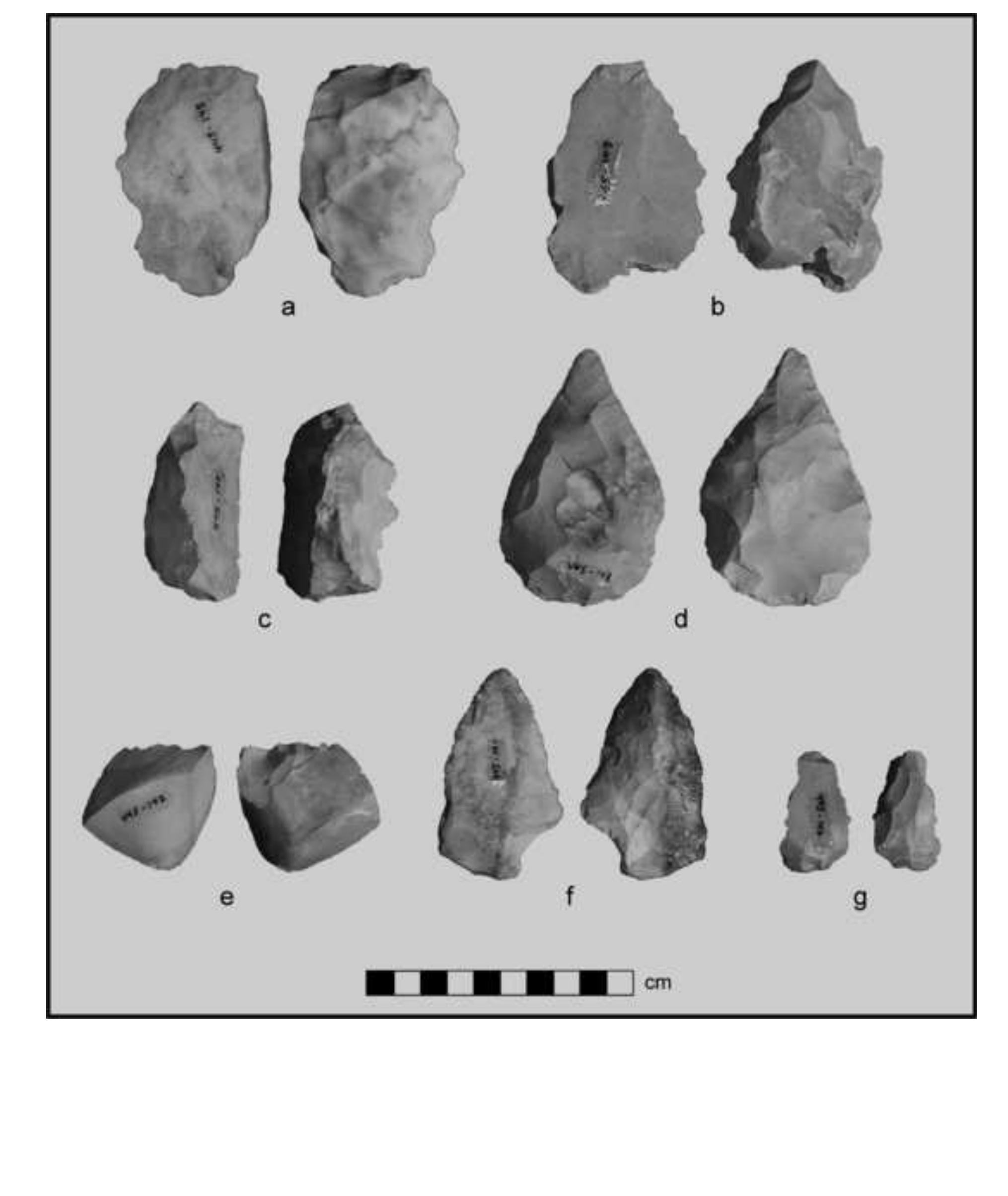

(1)

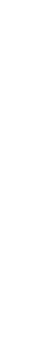




\section{Dak Table Captions}

Table 1. Calculating the effect of cosmic radiation: tooth at Snail Hill (Loc. Dak348): Field Sample D30, Analyzed Sample FT73.

Table 2. Analyzed sediment samples from Snail Hill and Bir Talata, Dakhleh Oasis. Mean of 3 at Snail Hill, from the Calcareous Silty Sediments Member of the Lake Teneida Formation (CSS). Mean of 10 from Bir Talata combines samples from the Red Mud (RML), the Older Sand Unit (OSU) and the Vent backdirt ('dredgeate'). Uncertainties reflect experimental uncertainties in isotope concentrations.

Table 3. Locations of ESR field and sediment samples, Dakhleh Oasis (see Figs. 5 and 7).

Table 4: $\quad$ Three analyzed tooth fragments from the same collection site: Field Sample D22 in Older Sand Unit (OSU), Bir Talata area, Dakhleh Oasis. Uncertainties reflect experimental uncertainties in $A_{\Sigma}$ and sediment dose.

Table 5. ESR results from Snail Hill (Loc. Dak348), Dakhleh Oasis. Uncertainties reflect experimental uncertainties in $\mathrm{A}_{\Sigma}$ and sediment dose.

Table 6. $\quad$ ESR ages of molluscs and tooth fragments from Bir Talata area, Dakhleh Oasis: breached artesian vent Dak447N (Vent); Red Mud lag area (RML) surface or near surface finds; Older Sand Unit (OSU), surface or near surface finds. Uncertainties reflect experimental uncertainties in $A_{\Sigma}$ and sediment dose.

Table 7. Frequency of ESR dates from Bir Talata area, Dakhleh Oasis, within Marine Isotope Stages 1 to 17 , showing timing of the Dakhleh meteoritic event and proposed correlations with archaeological finds in Dakhleh region. Developmental stages: TMSA, Terminal Middle Stone Age (might be considered Later Stone Age); YMSA, Younger Middle Stone Age; OMSA, Older Middle Stone Age; TESA, Terminal Earlier Stone Age; ESA, Earlier Stone Age (see Table 8).

Table 8. Pleistocene Cultural Stratigraphic Units and Developmental Stages recognized at Dakhleh and Kharga oases, related to evidence for habitability, using chronometric dates for sediments and fauna implying availability of water. Those in italics are selected as examples, related to environmental conditions during deposition: $(\mathbf{U}=$ $\left.{ }^{230} \mathrm{Th} /{ }^{234} \mathrm{U}\right)$, the life of a freshwater snail $(\mathrm{E}=\mathrm{ESR})$ or the life of an ostrich $\left(\mathrm{C}={ }^{14} \mathrm{C} \mathrm{AMS}\right.$ uncal). Those in bold are directly associated with an archaeological occurrence (U or $E$ ), on sediment that overlies or underlies the artefacts. MIS stages are not to scale. 
Dak Table 1

\begin{tabular}{|c|c|c|c|c|c|c|}
\hline $\begin{array}{c}\text { Sample } \\
\text { Snail Hill tooth } \\
\text { Analyzed FT73 }\end{array}$ & $\begin{array}{c}\text { Dcos } \\
(m G y / y)\end{array}$ & $\begin{array}{c} \pm \\
1 \sigma\end{array}$ & $A_{\Sigma}(G y)$ & EU (ka) & $\begin{array}{c}\text { ESR Age } \\
\text { LU (ka) }\end{array}$ & RU (ka) \\
\hline $\begin{array}{l}\text { Buried } \\
\text { constantly by } \\
\geq 15 \text { m seds. }\end{array}$ & 0 & \pm & $\begin{array}{c}543.7 \\
17.6\end{array}$ & $\begin{array}{l}119.6 \\
6.6\end{array}$ & $\begin{array}{c}201.2 \\
12.4\end{array}$ & $\begin{array}{c}451.8 \\
44.9\end{array}$ \\
\hline $\begin{array}{l}\text { Time-averaged } \\
\text { cosmic dose }\end{array}$ & 0.104 & \pm & $\begin{array}{c}543.7 \\
17.6\end{array}$ & $\begin{array}{c}117.4 \\
6.4\end{array}$ & $\begin{array}{c}195.4 \\
10.6\end{array}$ & $\begin{array}{c}420.5 \\
30.3\end{array}$ \\
\hline $\begin{array}{l}\text { Always fully } \\
\text { exposed }\end{array}$ & 0.293 & \pm & $\begin{array}{c}543.7 \\
17.6\end{array}$ & $\begin{array}{c}113.3 \\
6\end{array}$ & $\begin{array}{c}184.1 \\
10.6\end{array}$ & $\begin{array}{c}366.2 \\
30.3\end{array}$ \\
\hline
\end{tabular}


Dak Table 2

\begin{tabular}{|c|c|c|c|c|c|}
\hline \multirow{2}{*}{$\begin{array}{l}\text { Sediment } \\
\text { Samples } \\
\text { Locality }\end{array}$} & \multirow[b]{2}{*}{$\begin{array}{l} \pm \\
1 \sigma \\
\end{array}$} & \multicolumn{3}{|c|}{ Concentrations } & \multirow{2}{*}{$\begin{array}{c}\text { External } \\
\text { Dose } \\
\text { Rates } \\
\text { Dext, } \gamma \\
(m G y / y)\end{array}$} \\
\hline & & $\begin{array}{c}U \\
\text { (ppm) }\end{array}$ & $\begin{array}{c}\text { Th } \\
\text { (ppm) }\end{array}$ & $\begin{array}{c}K \\
\text { (wt\%) }\end{array}$ & \\
\hline $\begin{array}{l}\text { Snail Hill, Dak348 } \\
\text { Mean }(n=3)\end{array}$ & \pm & $\begin{array}{l}1.87 \\
0.25\end{array}$ & $\begin{array}{l}4.1 \\
1.5\end{array}$ & $\begin{array}{l}0.55 \\
0.28\end{array}$ & $\begin{array}{l}0.790 \\
0.101\end{array}$ \\
\hline $\begin{array}{l}\text { Bir Talata, Dak006 } \\
\text { Mean }(n=10)\end{array}$ & \pm & $\begin{array}{l}2.45 \\
1.46\end{array}$ & $\begin{array}{l}6.5 \\
2.5\end{array}$ & $\begin{array}{l}1.23 \\
0.45\end{array}$ & $\begin{array}{l}0.814 \\
0.217\end{array}$ \\
\hline $\begin{array}{l}\text { Bir Talata, Dak006 } \\
(\mathrm{D} 107)(\mathrm{n}=1)\end{array}$ & \pm & $\begin{array}{l}2.24 \\
0.02\end{array}$ & $\begin{array}{c}10.72 \\
0.70\end{array}$ & $\begin{array}{l}1.39 \\
0.04\end{array}$ & $\begin{array}{l}1.021 \\
0.071\end{array}$ \\
\hline
\end{tabular}


Dak Table 3

\begin{tabular}{|c|c|c|c|c|c|}
\hline \multicolumn{6}{|c|}{ GPS locations for ESR samples } \\
\hline $\begin{array}{l}\text { Locations and } \\
\text { Field Samples }\end{array}$ & $\begin{array}{c}\text { Geological } \\
\text { Context }\end{array}$ & Degre & ees North & \multicolumn{2}{|c|}{ Degrees East } \\
\hline \multicolumn{6}{|c|}{ Snail Hill, Locality Dak348 } \\
\hline $\begin{array}{l}\text { Trig. Point, N Knoll } \\
\text { top, } 151.1 \mathrm{~m} \text { a.s.l. }\end{array}$ & $\begin{array}{l}\text { CSS Member, Lake } \\
\text { Teneida Fm. }\end{array}$ & $25^{\circ}$ & $27.861^{\prime}$ & $29^{\circ}$ & $19.868^{\prime}$ \\
\hline $\begin{array}{l}\text { West face, Field } \\
\text { Sample D30, tooth }\end{array}$ & CSS, in situ & $25^{\circ}$ & $27.860^{\prime}$ & $29^{\circ}$ & $19.867^{\prime}$ \\
\hline $\begin{array}{l}\text { South face, Field } \\
\text { Sample D27, snails }\end{array}$ & CSS, in situ & $25^{\circ}$ & $27.854^{\prime}$ & $29^{\circ}$ & $19.871^{\prime}$ \\
\hline $\begin{array}{l}\text { Upslope area, } \\
\text { various field } \\
\text { samples, tooth } \\
\text { fragments }\end{array}$ & $\begin{array}{l}\text { Bir Talata area, } \\
\text { Red Mud, surface } \\
\text { lag in blowout area } \\
(\mathrm{RML})\end{array}$ & Locality & Dak006 & $29^{\circ}$ & $48.188^{\prime}$ \\
\hline $\begin{array}{l}\text { Downslope, } \\
\text { Field Sample D22, } \\
\text { tooth fragments }\end{array}$ & $\begin{array}{l}\text { Older Sand Unit, } \\
\text { slope, surface } \\
\text { exposure and sub- } \\
\text { surface (OSU) }\end{array}$ & $25^{\circ}$ & $38.463^{\prime \prime \prime}$ & $28^{\circ}$ & 48.073' \\
\hline $\begin{array}{l}\text { Base of slope, } \\
\text { Field Sample D106, } \\
\text { intact tooth }\end{array}$ & $\begin{array}{l}\text { Older Sand Unit, } \\
\text { basal contact, } \\
\text { surface exposure } \\
\text { (OSU) }\end{array}$ & $25^{\circ}$ & 38,433 & $28^{\circ}$ & $38.047^{\prime}$ \\
\hline $\begin{array}{l}\text { Breached Vent, } \\
\text { Loc. 447N, Field } \\
\text { Samples D18 \& } \\
\text { D20, snail shells } \\
\text { (Melanoides), }\end{array}$ & $\begin{array}{l}\text { Romano-Byzantine } \\
\text { backdirt = eye } \\
\text { sediments, in situ }\end{array}$ & $25^{\circ}$ & $38.584^{\prime}$ & $28^{\circ}$ & $47.872^{\prime}$ \\
\hline
\end{tabular}


Dak Table 4

\begin{tabular}{lcc}
\hline $\begin{array}{c}\text { Analyzed } \\
\text { Sample }\end{array}$ & $\mathbf{\pm 1 \sigma}$ & LU (ka) \\
\hline \multirow{2}{*}{ FT74C } & & 48.8 \\
& \pm & 5.3 \\
FT74B & & 106.4 \\
& \pm & 11.1 \\
FT74J & & 164.6 \\
& \pm & 15.5 \\
\hline
\end{tabular}


Dak Table 5

\begin{tabular}{|c|c|c|c|c|c|}
\hline $\begin{array}{l}\text { Snail Hill } \\
\text { Analyzed } \\
\text { Samples }\end{array}$ & $\pm 1 \sigma$ & $A_{\Sigma}(G y)$ & $\mathrm{EU}(\mathrm{ka})$ & $\begin{array}{l}\text { ESR Age } \\
\text { LU (ka) }\end{array}$ & RU (ka) \\
\hline $\begin{array}{l}\text { FT73 (D30) } \\
\text { (tooth) }\end{array}$ & \pm & $\begin{array}{c}543.7 \\
17.6\end{array}$ & $\begin{array}{c}117.4 \\
6.4\end{array}$ & $\begin{array}{c}195.4 \\
10.6\end{array}$ & $\begin{array}{c}420.5 \\
30.3\end{array}$ \\
\hline $\begin{array}{l}\text { RM61A (D27) } \\
\text { (mollusc) }\end{array}$ & \pm & $\begin{array}{l}59.2 \\
2.6\end{array}$ & $\begin{array}{l}84.1 \\
13.2\end{array}$ & $\begin{array}{l}87.2 \\
14.0\end{array}$ & $\begin{array}{l}89.3 \\
14.7\end{array}$ \\
\hline $\begin{array}{l}\text { RM68 (D28) } \\
\text { (mollusc) }\end{array}$ & \pm & $\begin{array}{l}62.9 \\
2.6\end{array}$ & $\begin{array}{l}88.0 \\
13.6\end{array}$ & $\begin{array}{l}91.2 \\
14.3\end{array}$ & $\begin{array}{l}94.1 \\
15.2\end{array}$ \\
\hline $\begin{array}{l}\text { Mean of } \\
\text { molluscs }(n=2)\end{array}$ & \pm & & $\begin{array}{l}86.1 \\
13.4\end{array}$ & $\begin{array}{l}89.3 \\
14.2\end{array}$ & $\begin{array}{l}91.8 \\
14.9\end{array}$ \\
\hline
\end{tabular}


Dak Table 6

\begin{tabular}{|c|c|c|c|c|c|c|c|}
\hline \multirow[t]{2}{*}{$\begin{array}{c}\text { Field } \\
\text { Sample } \\
\end{array}$} & \multirow[t]{2}{*}{$\begin{array}{c}\text { Analyzed } \\
\text { Sample }\end{array}$} & & \multicolumn{4}{|c|}{ ESR Age $( \pm 1 \sigma)$} & \multirow[t]{2}{*}{ MIS } \\
\hline & & & $A_{\Sigma}(G y)$ & EU (ka) & LU (ka) & RU (ka) & \\
\hline $\begin{array}{l}\text { D20 } \\
\text { Vent }\end{array}$ & RM62 & \pm & $\begin{array}{c}111.6 \\
6.0 \\
\end{array}$ & $\begin{array}{l}8.0 \\
0.7\end{array}$ & $\begin{array}{l}8.4 \\
0.7\end{array}$ & $\begin{array}{r}8.8 \\
0.8 \\
-\end{array}$ & 1 \\
\hline $\begin{array}{l}\text { D18 } \\
\text { Vent } \\
.\end{array}$ & RM60 & \pm & $\begin{array}{c}194.3 \\
5.4 \\
-\end{array}$ & $\begin{array}{c}14.2 \\
1.0\end{array}$ & $\begin{array}{c}14.9 \\
1.1\end{array}$ & $\begin{array}{c}15.4 \\
1.1 \\
-\end{array}$ & 2 \\
\hline $\begin{array}{c}\text { D22 } \\
\text { OSU slope }\end{array}$ & FT74C & \pm & $\begin{array}{c}171.5 \\
30.2\end{array}$ & $\begin{array}{c}31.2 \\
2.4 .\end{array}$ & $\begin{array}{c}48.8 \\
5.3\end{array}$ & $\begin{array}{c}112.6 \\
21.1\end{array}$ & 3 \\
\hline $\begin{array}{c}\text { D106 } \\
\text { OSU base }\end{array}$ & PT66C & \pm & $\begin{array}{c}135.6 \\
6.5\end{array}$ & $\begin{array}{c}63.1 \\
5.2\end{array}$ & $\begin{array}{c}84.0 \\
7.3\end{array}$ & $\begin{array}{c}115.9 \\
11.9\end{array}$ & \\
\hline $\begin{array}{l}\text { D101 } \\
\text { RML }\end{array}$ & PT67M & \pm & $\begin{array}{c}161.6 \\
11.2\end{array}$ & $\begin{array}{l}57.3 \\
4.8\end{array}$ & $\begin{array}{c}85.3 \\
7.8\end{array}$ & $\begin{array}{c}151.0 \\
18.3\end{array}$ & \\
\hline $\begin{array}{l}\text { D11 } \\
\text { RML }\end{array}$ & FT82 & \pm & $\begin{array}{c}311.4 \\
11.1\end{array}$ & $\begin{array}{l}56.3 \\
5.3\end{array}$ & $\begin{array}{l}93.7 \\
10.8\end{array}$ & $\begin{array}{c}198.4 \\
39.2\end{array}$ & \\
\hline $\begin{array}{l}\text { D101 } \\
\text { RML }\end{array}$ & PT67Z & \pm & $\begin{array}{c}101.1 \\
0,3\end{array}$ & $\begin{array}{c}93.3 \\
9.2\end{array}$ & $\begin{array}{l}98.4 \\
10.1\end{array}$ & $\begin{array}{c}101.8 \\
10.9\end{array}$ & \\
\hline $\begin{array}{l}\text { D10 } \\
\text { RML }\end{array}$ & FT79 & \pm & $\begin{array}{c}330.7 \\
7.1\end{array}$ & $\begin{array}{c}59.2 \\
4.6\end{array}$ & $\begin{array}{c}98.5 \\
9.9\end{array}$ & $\begin{array}{c}184.4 \\
30.8\end{array}$ & \\
\hline $\begin{array}{l}\text { D101 } \\
\text { RML }\end{array}$ & PT67N & \pm & $\begin{array}{c}116.4 \\
11.1\end{array}$ & $\begin{array}{c}69.9 \\
3.7\end{array}$ & $\begin{array}{c}99.7 \\
6.6\end{array}$ & $\begin{array}{c}147.4 \\
13.8\end{array}$ & 5 \\
\hline $\begin{array}{l}\text { D10 } \\
\text { RML }\end{array}$ & FT81 & \pm & $\begin{array}{c}341.1 \\
11.1\end{array}$ & $\begin{array}{c}60.7 \\
4.9\end{array}$ & $\begin{array}{c}101.2 \\
10.4\end{array}$ & $\begin{array}{c}215.6 \\
40.9\end{array}$ & \\
\hline $\begin{array}{l}\text { D22 } \\
\text { OSU }\end{array}$ & FT74B & \pm & $\begin{array}{c}355.5 \\
10.3\end{array}$ & $\begin{array}{c}66.3 \\
5.1\end{array}$ & $\begin{array}{c}106.4 \\
11.1\end{array}$ & $\begin{array}{c}203.5 \\
37.6\end{array}$ & \\
\hline $\begin{array}{l}\text { D22 } \\
\text { OSU }\end{array}$ & FT74A & \pm & $\begin{array}{c}332.1 \\
24.0\end{array}$ & $\begin{array}{l}65.9 \\
2.5\end{array}$ & $\begin{array}{c}106.6 \\
5.6\end{array}$ & $\begin{array}{c}194.7 \\
18.3\end{array}$ & \\
\hline $\begin{array}{l}\text { D22 } \\
\text { OSU }\end{array}$ & FT74X & \pm & $\begin{array}{c}365.7 \\
7.8\end{array}$ & $\begin{array}{c}65.9 \\
4.8\end{array}$ & $\begin{array}{c}106.8 \\
10.7\end{array}$ & $\begin{array}{c}206.2 \\
37.4\end{array}$ & \\
\hline $\begin{array}{l}\text { D10 } \\
\text { RML }\end{array}$ & FT80 & \pm & $\begin{array}{c}379.3 \\
10.3\end{array}$ & $\begin{array}{c}66.1 \\
5.1\end{array}$ & $\begin{array}{c}110.5 \\
11.1\end{array}$ & $\begin{array}{c}237.4 \\
44.4\end{array}$ & \\
\hline
\end{tabular}




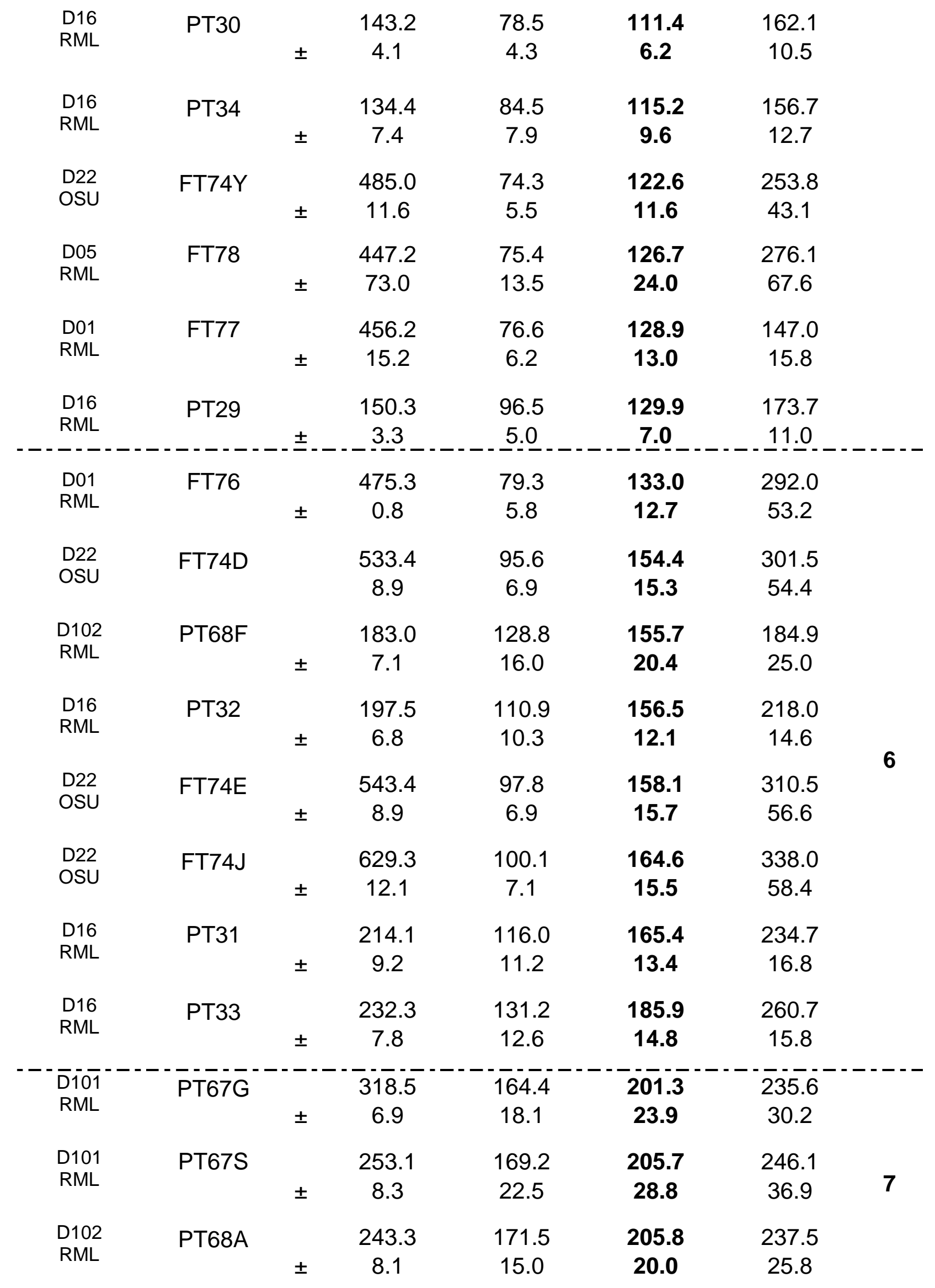




\begin{tabular}{|c|c|c|c|c|c|c|c|}
\hline $\begin{array}{l}\text { D16 } \\
\text { RML }\end{array}$ & PT36 & \pm & $\begin{array}{c}214.1 \\
9.2\end{array}$ & $\begin{array}{c}150.9 \\
10.5\end{array}$ & $\begin{array}{c}216.0 \\
13.5\end{array}$ & $\begin{array}{c}316.6 \\
18.0\end{array}$ & \\
\hline $\begin{array}{l}\text { D101 } \\
\text { RML }\end{array}$ & PT67E & \pm & $\begin{array}{c}315.3 \\
10.4\end{array}$ & $\begin{array}{c}161.6 \\
11.8\end{array}$ & $\begin{array}{c}218.4 \\
18.2\end{array}$ & $\begin{array}{c}307.4 \\
33.4\end{array}$ & \\
\hline $\begin{array}{l}\text { D101 } \\
\text { RML }\end{array}$ & PT67R & \pm & $\begin{array}{c}263.8 \\
7.4\end{array}$ & $\begin{array}{c}194.4 \\
16.6\end{array}$ & $\begin{array}{c}228.3 \\
22.1\end{array}$ & $\begin{array}{c}264.4 \\
29.1\end{array}$ & \\
\hline $\begin{array}{l}\text { D101 } \\
\text { RML }\end{array}$ & PT67P & \pm & $\begin{array}{c}352.4 \\
21.4\end{array}$ & $\begin{array}{c}250.3 \\
25.2\end{array}$ & $\begin{array}{c}229.1 \\
32.9\end{array}$ & $\begin{array}{c}352.0 \\
43.0\end{array}$ & \\
\hline $\begin{array}{l}\text { Di01 } \\
\text { RML }\end{array}$ & PT67F & \pm & $\begin{array}{c}304.3 \\
9.5\end{array}$ & $\begin{array}{c}235.2 \\
21.1\end{array}$ & $\begin{array}{c}270.4 \\
27.1\end{array}$ & $\begin{array}{c}324.5 \\
93.6\end{array}$ & 8 \\
\hline $\begin{array}{l}\bar{D} 1 \overline{01} \\
\text { RML }\end{array}$ & PT67D & \pm & $\begin{array}{c}364.6 \\
14.9\end{array}$ & $\begin{array}{c}255.4 \\
22.9\end{array}$ & $\begin{array}{c}307.0 \\
30.6\end{array}$ & $\begin{array}{c}364.0 \\
41.3\end{array}$ & 0 \\
\hline $\begin{array}{l}\text { D101 } \\
\text { RML }\end{array}$ & PT67K & \pm & $\begin{array}{c}410.0 \\
21.1\end{array}$ & $\begin{array}{c}271.2 \\
25.8\end{array}$ & $\begin{array}{c}334.2 \\
34.3\end{array}$ & $\begin{array}{c}379.2 \\
41.8\end{array}$ & $y$ \\
\hline $\begin{array}{l}\bar{D} 1 \overline{01} \\
\text { RML }\end{array}$ & РT67\% & \pm & $\begin{array}{c}393.6 \\
11.6\end{array}$ & $\begin{array}{c}292.2 \\
25.3\end{array}$ & $\begin{array}{c}342.0 \\
33.4\end{array}$ & $\begin{array}{c}394.4 \\
43.5\end{array}$ & 10 \\
\hline $\begin{array}{l}\text { D101 } \\
\text { RML }\end{array}$ & $\overline{\mathrm{PT}} \overline{6} \overline{\mathrm{Y}} \overline{\mathrm{Y}}$ & \pm & $\begin{array}{c}438.5 \\
14.6\end{array}$ & $\begin{array}{c}289.0 \\
25.0\end{array}$ & $\begin{array}{c}356.3 \\
34.0\end{array}$ & $\begin{array}{c}434.7 \\
47.9\end{array}$ & 11 \\
\hline $\begin{array}{l}\text { D101 } \\
\text { RML }\end{array}$ & PT67J & & $\begin{array}{c}501.3 \\
-15.2\end{array}$ & $\begin{array}{c}317.4 \\
-27.0\end{array}$ & $\begin{array}{c}397.6 \\
-37.0\end{array}$ & $\begin{array}{c}497.2 \\
-54.6 \\
\end{array}$ & 11 \\
\hline $\begin{array}{l}\text { D101 } \\
\text { RML }\end{array}$ & PT67W & & $\begin{array}{c}430.1 \\
58.1\end{array}$ & $\begin{array}{c}458.3 \\
-62.7\end{array}$ & $\begin{array}{c}468.4 \\
-54.8\end{array}$ & $\begin{array}{c}475.8 \\
-56.4\end{array}$ & 12 \\
\hline $\begin{array}{l}\text { D101 } \\
\text { RML }\end{array}$ & PT67C1 & \pm & $\begin{array}{l}889.1 \\
108.7\end{array}$ & $\begin{array}{c}543.9 \\
78.1\end{array}$ & $\begin{array}{l}687.6 \\
1022\end{array}$ & $\begin{array}{l}848.4 \\
134.4\end{array}$ & 17 \\
\hline
\end{tabular}


Dak Table 7

\begin{tabular}{|c|c|c|c|c|c|}
\hline MIS & $\mathbf{n}$ & EU (ka) & $\begin{array}{l}\text { ESR Age }^{a} \\
\text { LU (ka) }\end{array}$ & RU (ka) & Cultural Unit \\
\hline 1 & 1 & 8.0 & 8.4 & 8.8 & Masara \\
\hline 2 & 1 & 14.2 & 14.9 & 15.4 & $?$ \\
\hline 3 & 1 & 31.2 & 48.8 & 112.6 & $\begin{array}{l}\text { TMSA, Sheikh } \\
\text { Mabruk }\end{array}$ \\
\hline 5 & 17 & $57.3-96.5$ & $84.0-129.9$ & $151.0-173.7$ & $\begin{array}{c}\text { YMSA } \\
\text { Dakhleh + }\end{array}$ \\
\hline$(5 a)^{b}$ & --- & 63.1 & 84.0 & 115.9 & $\begin{array}{c}\text { (YMSA) } \\
\text { (Bir Talata) }\end{array}$ \\
\hline 6 & 1 & 79.3 & 133.0 & 292.0 & $\begin{array}{c}\text { YMSA } \\
\text { undefined }\end{array}$ \\
\hline \multicolumn{6}{|c|}{ Dakhleh Event $145 \pm 19$ ka $=$ adjusted $\sim 146 \mathrm{ka}$} \\
\hline 6 & 7 & $95.8-131.2$ & 154.4-185.9 & $184.9-338.0$ & $\begin{array}{l}\text { OMSA } \\
\text { Teneida }\end{array}$ \\
\hline 7 & 7 & $150.9-250.3$ & 201.3-229.1 & $235.6-352.0$ & Gifata \\
\hline 8 & 1 & 235.2 & 270.4 & 324.5 & $\begin{array}{l}\text { OMSA } \\
?\end{array}$ \\
\hline 9 & 2 & 255.4-271.2 & $307.0-334.2$ & $364.0-379.2$ & $\begin{array}{l}\text { OMSA? } \\
\text { TESA, Balat }\end{array}$ \\
\hline 10 & 1 & 292.2 & 342.0 & 394.4 & Balat \\
\hline 11 & 2 & $289.0-317.4$ & $356.3-397.6$ & $434.7-497.2$ & TESA/ESA? \\
\hline 12 & 1 & 458.3 & 468.4 & 475.8 & $\begin{array}{l}\text { ESA, Upper } \\
\text { Acheulian }\end{array}$ \\
\hline 17 & 1 & 543.9 & 687.6 & 848.4 & $\begin{array}{c}\text { Upper } \\
\text { Acheulian }\end{array}$ \\
\hline
\end{tabular}

a Ages calculated at $\pm 1 \sigma$ (see Table 6$)$.

b The only chronometric date at Dakhleh directly associated with an MSA unit. 


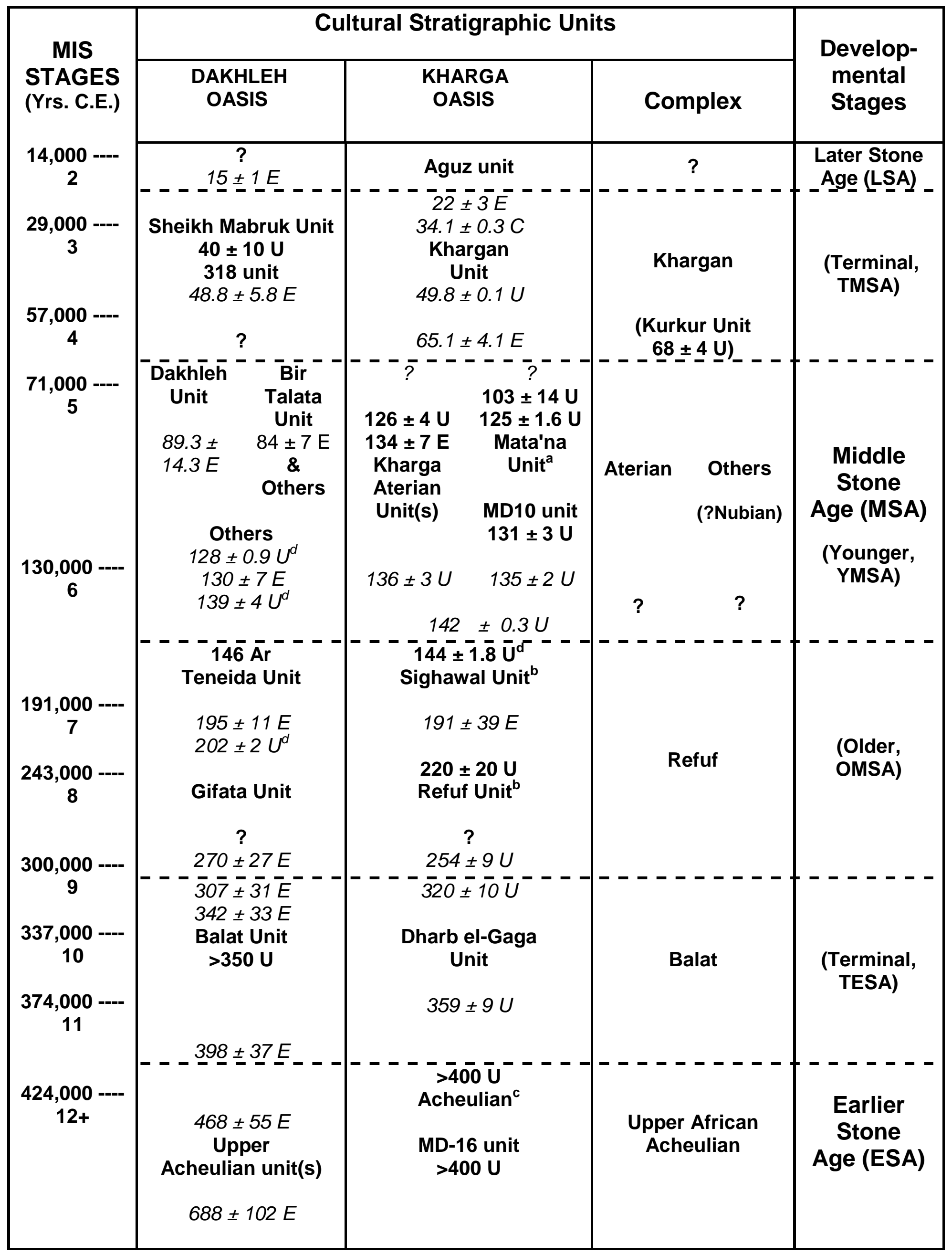



a Caton-Thompson, 1952, "Upper Levalloisian" at Refuf Locus VII and Mata'na G.
b Caton-Thompson, 1952, "Lower Levalloisian" at Refuf Locus IV.
c Caton-Thompson, 1952, "Acheulian" at Refuf Locus V.
d Previously unreported.

\section{Dak Table 8}

